\title{
REVISÃO
}

\section{IMUNOLOGIA DA LEISHMANIOSE TEGUMENTAR}

\section{Manoel Barral-Netto, Roberto Badaró, Aldlna Barral e Edgar M. Carvalho.}

\begin{abstract}
A leishmaniose cutânea se constitui num importante problema de saúde na América Latina; envolve uma extensa área das Américas, se estendendo da península de Yucatán no México até o norte da Argentina. Além das suspeitas de que a incidência das leishmanioses esteja aumentando, as sérias conseqüências das formas graves da doença levaram a Organização Mundial da Saúde a incluir as leishmanioses entre as seis doenças parasitárias escolhidas para estudo prioritário.
\end{abstract}

Os parasitas do gênero Leishmania têm ciclo biológico relativamente simples. No vetor invertebrado apresentam as formas promastigotas a qual, mede cerca de $10-15 \mu \mathrm{m}$ de comprimento por 1,5 a $3,5 u \mathrm{~m}$ de largura, tem aspecto fusiforme e flagelo único. Quando da alimentação dos flebotomineos as formas promastigotas são inoculadas no vertebrado; nestes animais o parasita assume a forma amastigota, com cerca de 2-4 $\mu \mathrm{m}$ de diâmetro, de forma arrendondada ou levemente ovulada, a qual tem vida predominantemente intracelular.

A ocorrência de leishmaniose clinicamente aparente em um hospedeiro está na dependência do tipo do parasita, da resistência natural do hospedeiro à infecção e da resposta imunológica contra o parasita que representa a resistência adquirida. A resistência natural do hospedeiro à infecção pela Leishmania foi bem determinada em camundongos infectados com Leishmania donovani quando Bradley 24 mostrou que a capacidade de resistir à infecção nas quatro primeiras semanas após a inoculação era controlada por um gen autossômico dominante localizado no cromossomo 1 e denominado de LSH1. Estudando a resistência à infecção por Leishmania tropica Howard, Hale e Chan-Liew ${ }^{71}$, determinaram que esta estava também controlada por um gen autossômico dominante. Todavia este gen é diferente do LSH e não se relaciona com o complexo $\mathrm{H}-2$.

Quando a Leishmania supera a resistência natural oferecida pelo hospedeiro e nele se estabelece,

\footnotetext{
Laboratório de Imunologia e Serviço de Anatomia Patológica do Hospital Professor Edgard Santos, Universidade Federal da Bahia Trabalho financiado pelo CNPq e pelo National Institutes of Health (AI-16282).

Endereço para correspondencia: Hosp. Frof. Edgard Santos, Rua João das Botas s/n Canela - 40.000 Salvador Bahia. Recebido para publicação em 4/9/1986.
}

entram em cena os mecanismos constituidos da resistência adquirida representado pela resposta imune.

\section{Penetração e Estabelecimento do Parasita}

A forma promastigota se aproxima do macrófago principalmente pelo pólo flagelar. Segue-se um contato que pode envolver qualquer parte do corpo parasitário 42107 , embora haja uma freqüência maior de adesão pela região do flagelo ${ }^{158}$. As evidéncias sugerem que não há direcionamento das promastigotas pelo flagelo, ao contrário o macrófago parece se dirigir até o parasita ${ }^{28}$.

Pearson e cols ${ }^{121}$ ao descreverem a interação entre as formas promastigotas de Leishmania donovani e fagócitos humanos salientam o fato de se formarem longos pseudópodos em torno do flagelo que se estendem ao corpo do parasita. O flagelo é rapidamente encarcerado porém a ingestão do corpo é mais lenta. Nos estudos realizados com macrófagos de roedores também são observados os longos pseudópodos, mas não há relato do retardo no fechamento dos pseudópodos em torno do corpo parasitário.

Agentes inibidores da fagocitose como a citocalasina B, diminuem o potencial infectivo da Leishmania mexicana para macrófagos humanos ou de camundongos "in vitro" 3156 , mas não diminuem a capacidade de penetração numa célula tumoral de baixo poder fagocítico ${ }^{84}$. Estes dados levaram à sugestão dos termos de "fagocitose induzida" 84 ou fagocitose "facilitada" 42 para caracterizar o processo de penetração parasitária.

Apesar de não terem sido descritas estruturas especiais da Leishmania que pudessem facilitar a sua penetração nas células, a Leishmania donovani pode infectar células de potencial fagocitico baixo como hepatócitos (in vivo) e fibroblastos da pele humana "in vitro" 41 . Estes dados sugerem uma participação ativa do parasita na fagocitose.

Não se conhecem com precisão as estruturas envolvidas na interação da superficie do macrófago e o parasita. É possivel que polissacarideos e monossacarideos já demonstrados na superficie das promastigotas sejam importantes 5455157 . Bray ${ }^{27}$ demonstrou a participação de um ligante envolvendo a aglutinina de germen de trigo na superficie da promastigota, a qual se liga a uma porção $\mathbf{N}$-acetil-glucosamina, como receptor no macrófago. Um mecanismo semelhante ao descrito para a ligação de Escherichia coli com células 144 . 
A possibilidade de penetração mesmo na ausência de soro sugere que receptores para a porção $\mathrm{Fc}$ de imunoglobulinas não são essenciais 122 . A participação de fatores de sistema complemento é difícil de ser avaliada devido ao fato dos macrófagos serem capazes de sintetizar alguns destes componentes. Vesiculas obtidas da membrana plasmática de macrófagos humanos se ligam, "in vitro", a promastigotas de Leishmania trópica, exibindo caracteristicas de uma interação receptor-ligante em termos de especificidade, saturabilidade, inibição competitiva e independência de temperatura; levando assim à suposição de existência de um ou mais locais intrínsecos de ligação ${ }^{80}$.

Vários estudos demonstraram a presença de antígenos parasitários na membrana de macrófagos infectados. A demonstração de tais antígenos foi realizada por imunofluorescência em macrófagos de camundongo 98 ou em macrófagos humanos 21 infectados por Leishmania donovani. Estes estudos evidenciam a possibilidade da apresentação de produtos parasitários aos linfócitos através do processamento antigènico pelos macrófagos. Uma demonstração mais direta desta apresentação de antigenos foi oferecida por Louis e cols 91 92, de que macrófagos parasitados ou pulsados com antigeno são capazes de estimular a proliferação de linfócitos sensibilizados.

A presença de antígenos parasitários na superficie dos fagócitos mononucleares pode funcionar como um estimulo para a proliferação de células $T$ ou a produção de anticorpos, mas é também possivel imaginar que tais macrófagos se tornem susceptiveis à destruição por linfócitos $\mathrm{T}$ citotóxicos ou por mecanismos de ADCC $\left({ }^{*}\right)$ mediados por outras células, como sugerido por Bryceson e cols 32 .

Células esplênicas imunes promovem a destruição "in vitro", de macrófagos parasitados 101, mas o mecanismo não está esclarecido.

Handman e cols ${ }^{66}$ estudando macrófagos de camundongos $\mathrm{Balb} / \mathrm{c}$ (susceptíveis à infecção por Leishmania tropica) e de CBA/H (moderadamente resistentes) mostraram que ambos apresentavam antigenos parasitários na superficie, após a incubação com antigeno bruto. Contudo, os macrófagos de camundongos $\mathrm{Balb} / \mathrm{c}$ não foram capazes de sensibilizar células singênicas para a reação de hipersensibilidade tardia ao antigeno, enquanto os macrófagos de $\mathrm{CBA} / \mathrm{H}$ o faziam. A incapacidade dos macrófagos de Balb/c foi relacionada com uma expressão funcional reduzida dos antígenos de histocompatibilidade na superficie celular, o que explicaria a alta susceptibilidade da linhagem. Também relacionando a exposição de antigenos pelo macrófago com o destino da infecção há um interessante relato de Gorczynski e MacRae ${ }^{59}$, mos-

(*) $\mathrm{ADCC}=$ Antibody Dependent Cellular Cytotoxicity. trando que células aderentes da pele de camundongos $\mathrm{Balb} / \mathrm{c}$ infectados por Leishmania trópica não induzem a proliferação de linfócitos de Balb/c, CBA ou da sua geração $F_{1}$. Salienta-se que os linfócitos das diferentes linhagens foram imunizados em camundongos $\mathrm{BCF}_{1}$ irradiados e reconstituidos com células de medula óssea. Uma indicação da boa regulação que existe nestes casos foi dada pelos mesmos autores, ao demonstrar que estas células aderentes de pele de camundongos $\mathrm{Balb} / \mathrm{c}$ são capazes de induzir eficientemente a proliferação linfocitária. Para isto é necessário que se utilize como fonte de antígeno fator excretado pelos parasitas ao invés do parasita vivo.

\section{Sobrevivência de Leishmania no Citoplasma do Macrófago}

O vacúolo parasitóforo se funde com lisossomas secundários, e disto pode resultar dano para as formas promastigotas, mas não para as formas amastigotas. Isto levou Lewis e Peters ${ }^{85}$ a sugerir que a sobrevivência da Leishmania está relacionada com a sua capacidade de transformar-se rapidamente em amastigota.

Várias diferenças foram descritas no tipo do vacúolo parasitóforo, variando desde a espécie até o estágio intracelular do parasita. No caso da Leishmania mexicana as formas promastigotas ou amastigotas induzem a formação de vacúolos diferentes em macrófagos de camundongo. Não foi comprovada, no entanto, qualquer relevância do tipo de vacúolo formado e a sobrevivência do parasita ${ }^{99}$.

Há dois tipos principais de vacúolos, um que circunda a Leishmania em estreita justaposição de membranas e vacúolos grandes, nos quais, aparece uma zona clara em torno do parasito. A fusâo dos lisossomas ocorre, principalmente, com os vacúolos largos, como demonstrado pelo depósito de material marcado ${ }^{44}$. Se estes vacúolos aparecem pela fusão repetida de vários lisossomas ou se resultam de pressão osmótica elevada no vacúolo não é assunto esclarecido.

Pouco se conhece sobre as necessidades nutricionais da Leishmania, principalmente das formas amastigotas. A demonstração da fusão de lisossomas com os vacúolos parasitóforos evidenciou que produtos do meio extracelular podem chegar até os parasitas, mediados pelo sistema vacuolar dos macrófagos ${ }^{44}$.

Para sobreviver no interior dos macrófagos a Leishmania não se utiliza de mecanismos como a inibição da fusão dos lisossomas com o vacúolo parasitóforo, como o Toxoplasma gondii ${ }^{75}$, ou o Mycobacterium tuberculosis ${ }^{8}$ ou o escape para o citosol, como o Trypanosoma cruzi ${ }^{81}$.

Embora desconhecidos os mecanismos que permitem a sobrevivência da Leishmania no interior 
do macrófago levanta-se a hipotese de que ou a Leishmania é refratária intrinsecamente, ou que produtos do parasita sejam capazes de degradar e/ou inativar as enzimas lisossomais. De qualquer maneira esta capacidade de sobreviver ao ataque enzimático é um atributo do parasita vivo, já que parasitas não viáveis quando fagocitados são prontamente digeridos.

A sobrevivência da Leishmania nas células fagociticas mononucleares depende da forma do parasita e da característica da célula fagocítica. Por exemplo, a fusão fagolisossomal pode resultar em dano para as formas promastigotas, mas não para as formas amastigotas. Por outro lado a capacidade de destruir a Leishmania varia se a célula efetora é um monócito ou se é um macrófago tecidual. Enquanto células retiradas do sangue periférico destroem promastigotas, células mononucleares cultivadas "in vitro" por mais que cinco dias perdem a capacidade de destruir estas formas permitindo que estas se transformem em formas amastigotas 112. Desta maneira a sobrevivència da Leishmania no macrófago logo após a infecção, pode também estar relacionada com a sua capacidade de transformar-se rapidamente em amastigotas, ou pelo fato da Leishmania infectar um macrófago residente o qual teria sua capacidade diminuida de destruir as formas promastigotas.

\section{RESISTÊNCIA ADQUIRIDA}

\section{ATIVAÇÃO CELULAR E DESTRUIÇÃO PARASITÁRIA}

A presença da Leishmania no interior do macrófago parece alterar pouco a capacidade funcional destas células ${ }^{29}$. A çapacidade de secreção extracelular e o potencial de destruição celular num mecanismo de citotoxicidade celular dependente de anticorpo (ADCC) permanecem inalterados exceto quando a carga parasitária é extremamente elevada. Passwell e cols ${ }^{119}$ demonstraram que a presença de Leishmania não altera a secreção normal de lisossoma, nem eleva a secreção de $\mathrm{PGE}_{2}$ ou do anionte superóxido em monócitos humanos.

Substâncias estimuladoras inespecificas do sistema fagocitico mononuclear, como o BCG, podem fornecer proteção contra a infecção de camundongo pela Leishmania tropica ${ }^{155}$. Por outro lado o mesmo agente empregado após o inicio da infecção murina pela Leishmania mexicana resultou em agravamento das lesões ${ }^{62}$. Avila e cols ${ }^{9}$ mostraram que o glucan também pode determinar inespecificamente resistência contra Leishmania braziliensis e Leishmania mexicana.

Após a fagocitose de microorganismos os leucócitos sofrem um processo de extrema ativação da cadeia respiratória, resultando numa rápida utilização de oxigênio molecular. Este fenômeno caracteriza a nivel bioquimico, o processo de ativação dos fagócitơs, o qual é avaliado pelo aumento da capacidade destas células de fagocitar, destruir e digerir os microorganismos.

A sobrevivência de qualquer parasita no interior do macrófago depende de um complexo balanço de influências que incluem: a) a habilidade do parasita em ativar ou não o metabolismo respiratório dos fagócitos; b) a capacidade do fagócito em elaborar produtos tóxicos intermediários do metabolismo do oxigênio; c) a resistência do parasita a tais produtos; e d) a disponibilidade de peroxidase.

A série de reaçōes enzimáticas do processo respiratório conduz à formação de produtos instáveis do oxigènio os quais são tóxicos para patógenos extracelulares e intracelulares. A redução do oxigênio para água leva à produção do anionte superóxido $\left(\mathrm{O}_{2}\right)$ e do peróxido de hidrogénio $\left(\mathrm{H}_{2} \mathrm{O}_{2}\right)$. Estes compostos reagem entre si e formam o radical hidroxila $(\mathrm{OH})$ e o oxigênio unimodal.

Diferentes estudos coincidem em mostrar que as formas promastigotas são susceptiveis de destruição por produtos do metabolismo oxidativo ${ }^{122}$. Entre os vários produtos tóxicos deste metabolismo o peróxido de hidrogênio se mostrou necessário e suficiente para a destruição da forma promastigota, a qual é deficiente em enzimas de degradação de $\mathrm{H}_{2} \mathrm{O}_{2}$, como o glutation peroxidase e a catalase ${ }^{112} 113$. $O$ mesmo autor demonstrou também que a forma amastigota é mais resistente ao ataque e contém quantidades substancialmente maiores destas enzimas. $O$ que ressalta porém na relação entre a forma amastigota e o macrófago é a capacidade do parasita penetrar nesta célula sem despertar a ativação do metabolismo oxidativo e por isto não induzir a formação dos produtos tóxicos.

A maioria das células ativadas "in vivo" não responde ao desafio com a forma amastigota; sugerindo que mecanismos moduladores presumivelmente ao nivel da membrana plasmática tornem estas células incapazes de responder a este estimulo. Por outro lado, células infectadas "in vivo" com amastigotas de Leishmania donovani não se tornam ativadas, indicando que este não é um estimulo adequado para ativação celular.

Em contraste com estes achados em macrófagos de camundongos está o trabalho de Pearson e cols 120 mostrando que em macrófagos humanos tanto as formas promastigotas quanto amastigotas estimulam a ativação do metabolismo respiratório. Neste caso a forma amastigota é melhor estimuladora que a promastigota. Os autores concluem que o metabolismo oxidativo não protege os macrófagos da infeç̧ão mesmo com as formas promastigotas. A discrepância com os dados obtidos de camundongos pode ser 
explicada pela intrinseca capacidade oxidativa baixa dos macrófagos humanos, associado à sua deficiência em mieloperoxidase. Nesta mesma linha de argumentação, os leucócitos polimorfonucleares humanos, capazes de uma elevada resposta respiratória e possuidores de mieloperoxidase, são mais eficientes na destruição da Leishmania.

Substâncias carreadoras de elétrons, como as fenazinas, tiazinas e quininas, quando em contacto com células vivas podem ser reduzidas a produtos intermediários auto-oxidáveis. No processo de reoxidação ocorre a geração de peróxido de hidrogênio $e$ anionte superóxido. Salientando a susceptibilidade da Leishmania a estes compostos, Rabinovitch e cols ${ }^{130}$ demonstraram que amastigotas ou promastigotas de Leishmania mexicana amazonensis são destruidas por baixas concentrações de meta-sulfato de fenazina e outros agentes transportadores de elétrons.

Ressaltando o papel desempenhado pelo parasita na resistência do ataque do macrófago ativado, Scott, Sacks e Sher ${ }^{142}$ mostraram diferenças de susceptibilidade entre diferentes cepas de Leishmania. Enquanto a Leishmania trópica (usando uma cepa que induz doença autolimitada no camundongo) foi destruida pelos macrofágos, a cepa Maria de Leishmania mexicana (a qual produz uma doença progressiva fatal nos camundongos) foi capaz de sobreviver no interior dos macrófagos ativados.

Analisando o outro pólo do binômio parasitahospedeiro diversos estudos têm avaliado o papel de macrófagos obtidos de diferentes origens. Usando principalmente diferentes espécies ou linhagens de animais nas quais o curso da doença difere. Revendo diversos dos seus próprios dados, e de outros pesquisadores, Mauel 99 relaciona uma extensa série de coincidências entre resistência e susceptibilidade "in vivo" com positividade e negatividade em diversos testes "in vitro". Sugerindo assim que resistência ou susceptibilidade a Leishmania seriam decorrentes de características intrínsecas, bioquímicas ou fisiológicas, do macrófago que facilitariam ou não o crescimento parasitário. $\mathrm{O}$ que é também afirmado por Nacy e cols. ${ }^{115}$ Em contrastę com a hipótese acima estão os dados que demonstram que macrófagos ativados por produtos de linfócitos, mesmo quando provenientes de linhagens de animais susceptiveis à infecção, são capazes de destruir Leishmania donovani 117 .

\section{PAPEL DOS LINFÓCITOS TE SEUS PRODUTOS}

Observaçōes clínicas e resultados de diversos sistemas experimentais conduziram à noção geralmente aceita de que a recuperação e a resistência imune à leishmaniose se devem ao componente celular da resposta imunológica, relegando a participaçāo humoral a um segundo plano.

As formas de leishmaniose cutânea que evoluem para cura espontânea são acompanhadas de marcante positividade nas reações de hipersensibilidade tardia em resposta a antígenos parasitários. A presença de anticorpos é observada de maneira irregular e apresenta títulos baixos.

Por outro lado, a ausência de resposta imunecelular se observa nas formas da doença que não apresentam cura espontânea e nas quais altos títulos de anticorpos especificos coexistem com o parasita, como na leishmaniose visceral e na leishmaniose cutâneo-difusa.

\section{Ativldades auxlliadoras}

Análise em conjunto de diversos estudos salienta o papel preponderante da imunidade mediada por células na recuperação da infecção também nos animais experimentais pelas diversas espécies de Leishmania. Estes achados são:

a) Animais que se recuperam espontaneamente da infecção leishmaniótica apresentam resposta imuno-celular ${ }^{34}$.

b) Procedimentos que diminuem a reatividade celular como indução de tolerância ou irradiação por raios $\mathrm{X}$ tornam as lesões mais graves 35 .

c) $\mathbf{A}$ indução de uma resposta de hipersensibilidade tardia, mesmo a antigeno não relacionado, no local da inoculação do pàrasita bloqueia o estabelecimento da leishmania ${ }^{18}$.

d) A preserça de resposta imune do tipo celular está presente nos animais resistentes e ausente nos animais susceptiveis à infecção por Leishmania 71 .

e) Experimentos de transferência passiva de células delimitam que o efeito protetor contra a Leishmania reside na população de linfócitos $T{ }^{129}$.

f) A resolução da infecção por Leishmania trópica nos camundongos "alto" e "baixo" respondedores tipo Biozzi è independente do nivel de anticorpos 65 .

Hill 69 acompanhou, através da transferência adotiva de imunidade, o desenvolvimento de resistência adquirida de camundongos $\mathrm{C} 3 \mathrm{H} / \mathrm{He}$ infectados pela Leishmania major. A resistência era medida através da capacidade dos animais receptores em inibir o crescimento de um inóculo parasitário padronizado. Determinou, deste modo, que a resistência adquirida se desenvolve rapidamente e alcança o nivel máximo quando ocorre a interrupção da multiplicação parasitária no local da lesão primária.

A visão geralmente aceita é que, em conformidade com outros patógenos intracelulares, a destruição de Leishmania é mediada pelos macrófagos ativados através das reaçōes imunocelulares. Outras interpretações seriam a de que linfócitos $T$ sensibili- 
zados especificamente 32 ou outras células como os polimorfonucleares 663 fossem citoliticos para o parasita extracelular ou para macrófagos infectados.

Os macrófagos de cobaia fagocitam e permitem a sobrevivência da Leishmania enrietti. Se tais macrófagos forem, porém, cultivados com linfócitos singênicos, que tenham sido estimulados (numa cultura mista de linfócitos ou pela Concanavalina A), eles são capazes de destruir a Leishmania enrietti ${ }^{102}$. $\mathrm{O}$ mesmo fenômeno foi observado por Coutinho $47 \mathrm{com}$ linfócitos sensibilizados por Leishmania major.

A Leishmania tropica é fagocitada e se multiplica no interior de macrófagos peritoneais não estimulados de camundongos. Neste modelo a exposição dos macrófagos à linfocina antes da infecção pelo parasita resultou num decréscimo da taxa de infecção; e os macrófagos que se tornaram infectados inibiram a multiplicação parasitária 117 .

O relato de Handman e cols ${ }^{67}$ no qual reconhecem no fator estimulador de colônias de macrófagos e granulócitos o papel ativo na estimulação dos macrófagos, não foi confirmado em estudos posteriores. Usando frações do sobrenadante de linhagem celular EL-4, Nacy e cols 116 sugerem que a fração responsável pela ativação macrofágica apresenta muitas semelhanças com o interferon gama. Utilizando sobrenadantes de linhagens celulares ricos em diferentes linfocinas, Titus e cols ${ }^{146}$, também atribuem a atividade parasiticida ao MAF/interferon gama.

Uma avaliação mais objetiva do papel dos linfócitos $\mathrm{T}$ no cursa da infecção, na cura das lesões e no desenvolvimento de resistência à reinfecção, necessita do estudo de populações homogêneas de linfócitos T especificamente sensibilizados para Leishmania. Louis e cols 92 desenvolveram "in vitro" linhagens celulares e clones de linfócitos $\mathrm{T}$ responsivos a antígenos de Leishmania trópica. $\mathrm{O}$ estudo de tais populações celulares demonstrou que elas expressavam fenótipo Lyt 1+2-, colaboravam com linfócitos B na produção de anticorpos. Quando especificamente estimuladas, eram capazes de produzir linfocinas ativadoras de macrófagos (para ação leishmanicida). Estas células também transferiram a reatividade para a reação de hipersensibilidade cutânea tardia, quando inoculadas em camundongos normais ${ }^{88}$. As populações celulares homogêneas realizam assim, "in vitro", todas as funções linfocitárias correlacionadas com a proteção do hospedeiro e apresentam caracteristicas fenotipicas e funcionais de células auxiliadoras. Paradoxalmente, quando injetadas em camundongos infectados estas células promovem um agravamento das lesōes ${ }^{87}$. Isto sugere que a susceptibilidade à leishmaniose cutânea pode estar associada a um funcionamento normal dos linfócitos $T$. Nestes casos os linfócitos $T$ poderiam estar atraindo macrófagos permissivos ${ }^{147}$. Neste caso a susceptibilidade seria decorrência de um defeito intrínseco do macrófago 17115 , de algumas subpopulações macrofágicas 59 ou do limiar de ativação dos macrófagos nos animais susceptiveis ${ }^{19}$. Há outras sugestões de um funcionamento normal, ou até exacerbado, do componente linfocitário $T$ nas linhagens susceptiveis. BarralNetto e cols ${ }^{15}$ demonstraram um aumento da produção de interleucina-2 em camundongos Balb/c no curso da infecção por Leishmania mexicana amazonensis; e Titus e cols ${ }^{145}$ obtiveram um efeito curativo na infecção de Balb/c por Leishmania major, com o uso de anticorpo monoclonal anti-L3T 4, o qual impede a ativação da célula $T$ por antígeno.

\section{PAPEL DOS LINFÓCITOS B E ANTICORPOS}

Embora existam anticorpos contra Leishmania em praticamente todas as formas de leishmaniose tegumentar, a sua presença $e$ intensidade não se correlaciona com proteção do hospedeiro. Nos modelos de leishmaniose murina também não foi demonstrado qualquer efeito protetor do soro imune ${ }^{99}$.

As linhagens de camundongos selecionadas por Biozzi pelas suas características de marcante ou discreta produção de anticorpos contra antigenos naturais, são conhecidos como "alto" e "baixo" respondedores. Os camundongos "alto" respondedores produzem altos titulos de anticorpos anti-Leishmania quando infectados por Leishmania tropica, mas têm uma baixa atividade macrofágica, e neles se desenvolvem lesões ulcerativas progressivas e graves. Inversamente os "baixo" respondedores, com baixos titulos de anticorpos mas intensa atividade macrofágica, desenvolvem uma doença menos grave e de cura espontånea ${ }^{65}$. Os mesmos autores também demonstraram que a irradiação de camundongos infectados pela Leishmania tropica, em niveis capazes de abolir a produção de anticorpos, não interferindo com as células $\mathbf{T}$ supressoras, não modifica o curso da lesão,

Outras evidências de que anticorpos não protegem o hospedeiro contra o estabelecimento de infecção foram observadas em experimentos com Leishmania trópica, nos quais a transferência de soro obtido de animais imunizados (e resistentes à infecção) para animais isogênicos não alterou o curso da doença nos animais receptores; apesar do uso, iniciado antes da infecção, de quantidades abundantes de soro imune e por um periodo prolongado de tempo ${ }^{74}$.

Sacks e cols 137 avaliaram o curso da infecção por Leishmania major ou Leishmania mexicana amazonensis em camundongos resistentes $(\mathrm{C} 3 \mathrm{H} / \mathrm{HeJ})$ ou susceptíveis (Balb/c) os quais foram tornados deficientes em linfócitos $B$ pelo tratamento com soro anti-IgM de camundongo desde o nascimento. $O$ curso da infecção do animal resistente não foi alterado, e, 
mais importante, na ausência de anticorpos o camundongo Balb/c permaneceu com os testes de hipersensibilidade cutânea tardia positiva e foi capaz de controlar o crescimento da lesão.

Apesar de não serem benéficos, ou mesmo serem prejudiciais à proteção e à resolução das lesões, os anticorpos podem estar envolvidos em outros fenômenos, dos quais o mais importante aparece ser a modulação da interação parasita-macrófago.

\section{a. Anticorpos citofílicos e opsonização}

Utilizando soro imune de coelho contra amastigotas e avaliando a infeç̧ão de macrófagos ou polimorfonucleares humanos em cultura, Chang ${ }^{43}$ observou que havia um decréscimo no número de amastigotas de Leishmania donovani no interior das células. $O$ uso de parasitas opsonizados levava aos mesmos resultados, porém menos marcantes. Pelo estudo da cinética da reação e com a utilização de células de pacientes com doença granulomatosa crônica (deficientes no metabolismo oxidativo) o autor concluiu que a diminuição do número de parasitas no interior das células humanas se devia a uma inibição da fagocitose na presença do soro imune.

Ao estudar o efeito do soro obtido de camundongos C 57B 1/6 re-infectados, Herman 68 observou a presença de anticorpos citofílicos e opsônicos para as formas amastigotas de Leishmania donovani, em soro obtido no periodo inicial de re-infecção. $O$ efeito final foi um aumento da aderência e ingestão dos parasitas. Ao avaliar o soro obtido em periodo mais tardio a percentagem de macrófagos capazes de ingerir parasitas estava maior ou igual ao nivel obtido com o uso do soro controle normal. Pearson e cols ${ }^{121}$ relataram que a ausência de soro reduz a fagocitose de Leishmania donovani por macrófagos humanos. Reis e cols 132 (enviado para publicação) estudaram o efeito do soro de camundongos susceptiveis (Balb/c) ou resistentes (C57B1/6) infectados por Leishmania mexicana amazonensis. Mostraram que o soro de ambas as linhagens aumenta a interiorização dos parasitas nos macrófagos, porém somente quando obtido na fase tardia de infecção ( 7 semanas ou 5 meses). Mais ainda foi mostrado que a absorção de anticorpos antiLeishmania reduz, ou abole, o efeito facilitador da penetração nestes soros. Estes dados ilustram que anticorpos podem alterar a interação da Leishmania com o macrofago, e mais ainda que este efeito pode ser diferente de acordo com o período de infecção.

$O$ aumento da fagocitose não resulta, todavia num efeito protetor do soro. A penetração da Leishmania num macrófago não ativado (ou incapaz de ser ativado) pode facilitar a sobrevivência do parasita. Visto assim, o efeito de aumentar a fagocitose pode ou não ser protetor para o hospedeiro, a depender do estado de ativação dos macrófagos. Já a capacidade dos anticorpos em diminuir a fagocitose poderia se correlacionar com proteção do hospedeiro ao evitar que o parasita alcance a célula onde se reproduz, e por expor a Leishmania aos efeitos citotóxicos do soro e à ação dos polimorfonucleares.

Diversos estudos 100128129 mostraram que apesar do soro não ter uma atividade protetora isoladamente ele pode apresentar um efeito sinergístico na proteção oferecida pela transferência de células imunes. Nestes estudos não se demonstrou claramente se o efeito sérico decorria da presença de anticorpos, ou de outros fatores.

\section{b. Ativação policlonal}

Várias doenças parasitárias cursam com uma hipergamaglobulinemia policlonal, entre as quais a leishmaniose visceral. A presença de produtos parasitários poderia ser capaz de causar uma ativação policlonal de linfócitos $B$, seguida de uma produção exacerbada de imunoglobulinas pelos plasmócitos, levando à hipergamaglobulinemia.

No modelo da infecção do camundongo Balb/c pela Leishmania tropica observa-se esplenomegalia e acentuada hipergamaglobulinemia. Neste sistema Weintraub e Gottlieb 154 demonstraram uma ativação policlonal de células B durante o curso da infecção, a qual foi evidenciada por aumento no número de precursores esplênicos de linfócitos B contra antígenos não relacionados com Leishmania. Identificaram ainda a presença de um mitógeno de linfócitos B no material obtido pela lise de promastigotas de Leishmania tropica. Colle e cols ${ }^{45}$ demonstraram ativação policlonal no curso de doença visceral por Leishmania tropica em camundongos Balb/c e C57B1/6. Na leishmaniose cutânea ou mucosa humana não há hiperglobulinemia nem evidencia de ativação policlonal.

\section{OUTRAS CÉLULAS}

Kirkpatrick e Farrel ${ }^{78}$ avaliaram o papel das células NK ("natural killer") na infecçao por Leishmania tropica ou Leishmania donovani usando camundongos "beige" (os quais apresentam vários defeitos, entre os quais uma acentuada deficiência de atividade NK), e usaram como controles camundongos heterozigotos (fenotipicamente normais). $\mathrm{O}$ curso da infecção por Leishmania tropica em camundongos "beige" foi semelhante ao dos controles, e a resposta imune humoral ou celular foi semelhante em ambos os grupos. Por outro lado, os camundongos "beige" foram incapazes de eliminar as amastigotas de Leishmania donovani, a respeito da presença da resposta imunocelular e humoral semelhante ao grupo controle, 
sugerindo assim um papel das células NK na recuperação da infecção por Leishmania donovani. Em trabalho posterior os mesmos autores 79 avaliaram a atividade de células NK em diversas linhagens de camundongos infectados por Leishmania donovani e não encontraram correlações consistentes entre susceptibilidade ao parasita e atividade NK espontânea, nem um padrão consistente de ativação ou depressão de atividade NK após a infecção.

\section{ATIVIDADE SUPRESSORA}

Scott e Farrell 141 estudando camundongos Balb/c infectados pela Leishmania tropica observaram uma depressão na capacidade proliferativa de linfócitos em resposta ao estímulo com mitógenos. Identificaram uma população de células aderentes capaz de suprimir a resposta imune "in vitro". A caracteristica aderente, e a demonstração de que a supressão podia ser eliminada pela indometacina, sugeriam a participação do macrófago mediando a supressão pela sintese de prostaglandinas.

$\mathrm{Na}$ leishmaniose cutânea difusa no homem foi identificada uma população de células aderentes no sangue periférico capaz de inibir seletivamente a resposta proliferativa de linfócitos ao estímulo com antígeno de Leishmania, deixando preservada a resposta aos mitógenos e antigenos não relacionados. Esta população também tinha o seu efeito supressor revertido com o uso de indometacina 126127.

A infecção do camundongo Balb/c pela Leishmania tropica ou Leishmania mexicana resulta numa doença progressiva não controlada com grande multiplicação parasitária e dișseminação por todo o corpo. Nestes animais a resposta imunocelular é inicialmente positiva, avaliada tanto pelos testes de hipersensibilidade cutânea tardia quanto pela proliferação de linfócitos "in vitro" após estimulação por antígenos parasitários. Esta resposta imune desaparece nos estágios mais tardios, diferentemente dos animais resistentes nos quais a resposta imune mediada por células permanece positiva por longo tempo 1381 . Freqüentemente se atribui o fenômeno de desaparecimento da resposta imunocelular de comundongos susceptiveis à ação de uma célula supressora. Leclerc e cols ${ }^{83}$, todavia, atribuem o fenómeno à depleção de células imunocompetentes no baço de animais infectados, o qual seria constituido por uma grande população de células "nulas".

Diversas manipulações realizadas no camundongo Balb/c (altamente susceptivel à Leishmania) sugerem a presença de uma célula $T$ supressora, a qual seria responsável pelo desaparecimento da resposta imunocelular potencialmente efetiva, e pelo curso grave da infecção. Os camundongos infectados e submetidos à irradiação sub-letal (em níveis capazes de destruir os precursores das células $T$ supressoras) têm um curso de infecçāo menos grave e semelhante ao do animal resistente. Quando tais animais recebem linfócitos $\mathrm{T}$ de camundongos normais observa-se de novo o curso grave e fatal da doença 73 .

De maneira similar a reconstituição de camundongos atimicos, os quais têm doença menos grave que os camundongos Balb/c normais, resulta numa doença crônica e de curso fatal; sugerindo a implicação da célula $T$ e de resposta $T$-dependentes no desaparecimento de resposta imune protetora do hospedeiro 72 . Foi sugerido que um defeito primário do macrófago leva à geração dos linfócitos $\mathrm{T}$ supressores, e esta população foi caracterizada fenotipicamente como Lyt 1 +2 - e I-J -.

Gorczynski e MacRae ${ }^{59}$ demonstraram que a estimulação de linfócitos usando uma população infectada de células aderentes da pele de camundongos $\mathrm{Balb} / \mathrm{c}$ leva ao aparecimento de uma população celular (Thy $-1.2^{+}$, Lyt $-2^{+}$, incluindo células Lyt $-1^{+}$). Estas células são capazes de inibir a subseqüente sensibilização de células normais de linfonodos de camundongos (Balb/c x CBA) $\mathrm{F}_{1}$ por antigeno de Leishmania tropica. Reforçando assim as evidências da atividade de uma célula supressora como sendo responsável pelo curso grave da doença no camundongo Balb/c.

Recentemente Liew 86 relatou a obtenção de linhagem celular homogênea de linfócitos $\mathrm{T}$, com as mesmas caracteristicas fenotípicas descritas acima, $e$ que é capaz de suprimir a proliferação linfocitária "in vitro" e a reatividade cutânea tardia contra antigenos de Leishmania tropica. Quando injetadas em camundongos, juntamente com promastigotas de Leishmania tropica, as células promovem um agravamento das lesões.

\section{MECANISMOS DE SOBREVIVÊNCIA DA LEISHMANIA}

É evidente que para se estabelecer no hospedeiro e nele sobreviver e se multiplicar a Leishmania deve ser capaz de resistir e superar as diversas barreiras e ataques utilizados pelos vertebrados.

Sendo a forma promastigota extremamente sensivel ao ataque lítico do soro devemos imaginar existir alguma forma de proteção até que ocorra a penetração no macrófago e sua transformação em amastigotas. Embora sem evidências experimentais, Pearson e cols 122 sugerem que a saliva ou outros elementos do flebótomo podem revestir ou proteger a promastigota ou alternativamente, inativar, localmente, o complemento.

Há demonstrações que a promastigota é capaz de promover o re-arranjo com polarização ("capping") dos anticorpos localizados na sua superfície ${ }^{53}$. Este 
processo no entanto é lento e não preveniria a ativação do Sistema Complemento. Por outro lado, a liberação dos complexos antigeno-anticorpo poderia bloquear receptores $\mathrm{Fc}$ de células potencialmente destruidoras como polimorfonucleares neutrófilos e eosinófilos.

As promastigotas que escapam ao ataque litico do soro, e presumivelmente dos polimorfonucleares, penetrariam então nos macrófagos. Embora tenha sido documentado que macrófagos peritoneais de camundongos são ativos na destruição das promastigotas através de produtos do metabolismo oxidativo, devemos supor que haja mecanismos de sobrevivência mesmo ai. Várias alternativas são possiveis. Uma delas é que os macrófagos da pele dos camundongos, a exemplo dos macrófagos derivados dos monócitos circulantes humanos tenham uma menor atividade destruidora pelos metabolitos da cadeia respiratória e por isto permitam a sobrevivencia do parasita. Podemos imaginar também que apesar do ataque realizado pelo macrófago alguns parasitos sobrevivam; seja por uma resistência intrínseca, de certas populações parasitárias mais patogênicas, seja por um esgotamento da atividade macrofágica. Alternativamente, há também a possibilidade de que as leishmanias sobrevivam no interior de outras células; idèia que tem suporte na demonstração da capacidade da Leishmania se transformar de promastigota em amastigota, nos fibroblastos de pele humana "in vitro" 44 . Porém nestas células o crescimento parasitário não parece ser eficiente ${ }^{51}$.

Uma vez transformada em amastigota, ou no macrófago ou em outras células, a infecção progrediria mais facilmente com a invasão de novos macrófagos porque a forma amastigota é capaz de penetrar nos fagócitos mononucleares sem promover a exacerbação do metabolismo respiratório.

Não há demonstrações claras dos mecanismos utilizados pela Leishmania para resistir ao ataque enzimático que se segue à formação do fagolisossoma. Gottlieb e Dwyer 60 demonstraram a presença de atividade de fosfatase ácida na superficie externa da membrana da Leishmania donovani (promastigotas). Esta localização particular da enzima pode, hipoteticamente, auxiliar a Leishmania de duas maneiras: protegendo-a dos mecanismos microbicidas e permitindo a utilização de fosfatos orgânicos do meio para obtenção de nutrientes. Esta e/ou outras enzimas e diferentes mecanismos poderiam constituir uma estrutura própria da Leishmania que lhe permitisse resistir ao ataque enzimático. Há também a possibilidade de que a Leishmania produza materiais capazes de inativar ou interferir com as enzimas lisossomiais.

Este material se constitui num polissacáride complexo e que é capaz de reverter a resistência de macrófagos não permissivos e promover o crescimento parasitário.
Embora não saiba seu modo de ação é de se imaginar que interfira com os mecanismos utilizados pelo macrófago para a destruição dos parasitos.

\section{RESPOSTA IMUNE E AS DIFERENTES FORMAS CLÍNICAS DE LEISHMANIOSE TEGUMENTAR}

O envolvimento tegumentar da leishmaniose pode se traduzir clinicamente por manifestações diversas tais como lesão cutânea ulcerada única, lesões cutâneas múltiplas, lesão nodular única ou disseminada, processos infiltrativos e envolvimento de mucosa. As diversas manifestações clínicas observadas na leishmaniose tegumentar estão na dependência de vários fatores tais como a espécie de Leishmania, os aspectos genéticos do hospedeiro e com a resposta imunológica contra os antigenos parasitários. A importância da cepa é bem caracterizada na África onde a leishmaniose cutânea difusa está ligada à infecção pela Leishmania aethiopica 53 e na América do Sul onde o envolvimento de mucosas é predominantemente associado ao complexo Leishmania braziliensis 4096 . Todavia a mesma cepa de Leishmania pode também induzir diferentes formas clínicas da doença. Assim é que lesão cutânea clássica pode ser causada por Leishmania aethiopica, e a Leishmania mexicana amazonensis pode tanto produzir uma lesão localizada $\mathrm{e}$ às vezes auto-resolutiva, como lesão mucosa ou leishmaniose cutânea difusa ${ }^{1361}$. Existe uma carência de estudos avaliando o papel da constituição genética no aparecimento das diversas formas clínicas das leishmanioses. Isoladamente alguns relatos têm chamado atenção para associação entre o tipo ou gravidade da doença e alguns grupos raciais. Por exemplo, nos Andes, Walton e Valverde ${ }^{152}$ documentaram que embora os descendentes dos indios fossem mais acometidos pela leishmaniose, as formas graves da doença predominavam em individuos cujos ancestrais eram da raça negra. No nosso meio tem sido documentado uma predileção de raça no desenvolvimento da doença mais grave e outros fatores de risco tais como o número de lesões cutâneas, a localização destas, a utilização de esquema terapêutico não adequado se correlacionam com o aparecimento de lesões mucosas da doença 899097 .

A importância da resposta imune no aparecimento das diversas formas clínicas de leishmaniose cutânea passou a ocupar uma posição de destaque após a documentação da existência de formas polares de leishmaniose tais como se observa na lepra ${ }^{148}$. Estas formas polares estão representadas de um lado pela leishmaniose cutânea, histologicamente caracterizada como um processo granulomatoso tipo tuberculóide com proliferação linfocitária e plasmocitária e ausência ou escassez de parasitas, e do outro lado, pela 
leishmaniose cutânea difusa, onde existe uma infiltração dérmica de macrófagos, habitualmente vacuolados, cheios de parasitas, e com ausência de linfócitos. Entre estas duas formas denominadas de TT (tuberculóide) e MM (macrófago), Bryceson ${ }^{35}$ caracterizou ainda as seguintes formas: MI (macrófago intermediária), II (intermediária) e IT (intermediária tuberculóide). Tentativas de aplicabilidade desta classificação imunológica na leishmaniose tegumentar americana tem sido dificeis e outras classificações têm sido propostas como a de Ridley 134 e Magalhães e cols 95 . Todavia a grande dificuldade de aplicabilidade destas classificações do ponto de vista imunológico é a falta de correlação entre a histopatologia e a resposta imune analisada por testes "in vivo" $e$ "in vitro" nas formas intermediárias e na forma tuberculóide, às quais representam as formas clinicas mais comuns da leishmaniose tegumentar. Faz exceção a esta regra a leishmaniose cutânea difusa na qual muitos parasitas são encontradas na lesão e onde é bem documentada "in vivo" e "in vitro" a incapacidade dos pacientes de responder a antigenos de Leishmania 33127 . A supressão da resposta imune na leishmaniose cutânea difusa é restrita à área celular, desde que a produção de anticorpos anti-Leishmania é preservada ${ }^{127}$. É também antígeno especifica, desde que estes pacientes têm a capacidade de responder "in vivo" e "in vitro" a outros antígenos com PPD ${ }^{126}$, embora alterações mais amplas da resposta imune celular tenham sido documentadas como ausência de resposta a teses intradérmicos a vários antígenos 3169 .

O mecanismo da imunossupressão a antígeno de Leishmania, foí recentemente estudado por Petersen e cols 127 , que avaliando pacientes com leishmaniose cutânea difusa na República Dominicana demonstrou que a depleção de células aderentes ou a adição de indometacina a culturas de células, restaurava a resposta blastogênica "in vitro" a antígenos de leishmania. Suportando a hipótese de que as células supressoras seriam os macrófagos, existe a demonstração de que co-cultivando linfócitos de pacientes, com macrófagos de indivíduos sadios que possuem a mesma constituição antigênica do Locus $D$ do sistema HLA das células dos pacientes, pode-se restaurar a resposta blastogênica a antigeno de Leishmania ${ }^{126}$. O mecanismo pelo qual os macrófagos exercem a supressão da resposta imune na leishmaniose cutânea poderia estar relacionado com a sintese de prostaglandinas desde que indometacina reverta o efeito supressor. Alternativamente, um defeito do macrófago no que concerne a sua capacidade de processar e apresentar os antígenos parasitários à célula $T$ poderia se constituir no mecanismo desta anormalidade.

Embora os macrófagos representem, provavelmente, as células que diretamente estão envolvidas na supressão da resposta imune na leishmaniose cutânea difusa, mecanismos alternativos como participação direta de linfócitos $T$ supressores neste fenómeno não pode ser afastada. Mesmo sem uma base imunológica, também existe a idéia de que a doença progride em virtude do fato de linfonodos encontrarem-se alterados, desde que obstrução linfática e processos infecciosos secundários são encontrados nos membros inferiores dos pacientes, sitio habitualmente inicial da lesão leishmaniótica na forma difusa da doença ${ }^{31}$.

A idéia de que o espectro clínico-patológico das leishmanioses é dependente da resposta imune do hospedeiro é atraente e em determinadas situações bem caracterizada. Este aspecto foi recentemente revisto por Grimaldi 61 e neste contexto teriamos inicialmente as formas localizadas e ou auto-resolutivas onde a resposta imune celular estaria presente $e$ por conseguinte a doença seria limitada. Não sendo a Leishmania contida nesta fase inicial da infecção, poderia haver progressão da doença por duas maneiras. O primeiro caso estaria representado pelas formas enérgicas nas quais a resposta celular estaria ausente $e$ conseqüentemente os macrófagos estariam repletos de Leishmania (leishmaniose cutânea difusa). No segundo caso, teriamos as chamadas formas alérgicas, nas quais o parasita é escasso ou mesmo invisivel na lesão, a imunidade celular seria facilmente detectada, mas diferente do que ocorreria nas formas autoresolutivas a doença progrediria. No último grupo estaria a forma recidiva de lesão cutânea também chamada de crônica e a úlcera muco-cutânea secundária ou espúndia. Todavia a correlação entre a resposta imune e as diversas formas clinicas da leishmaniose tegumentar americana é por muitas vezes complexa, porque na grande maioria dos casos os pacientes se apresentam com a resposta imune celular preservada apesar da ocorrência de manifestações clinicas diversas. Alternativamente, aspectos imunológicos e patológicos podem ser diferentes na vigência da mesma forma clínica da doença. Comprovando esta última situação, Pereira encontrou que de 16 pacientes com lesão mucosa no oeste do Brasil, 6 não apresentavam resposta ao teste intradérmico a antígeno de Leishmania e em dois deles havia um considerável número de parasitas na lesão, aspecto diverso do observado na maioria das séries nas quais o comprometimento da mucosa se associa à ausência ou escassez do parasita 2294109 . Alterações da resposta imune como ausência de resposta a testes intradérmicos e antígenos heterólogos e diminuição de linfócitos $\mathrm{T}$ foram também documentados em muitos destes pacientes avaliados por Pereira ${ }^{124}$, achados que também não têm sido documentados em pacientes com lesão cutânea ou lesão cutâneo-mucosa ${ }^{37}$.

Excluindo a observação de Pereira 124 os estudos da resposta imune celular em pacientes com 
leishmaniose tegumentar americana mostram que esta é intacta quando avaliada através da reação de Montenegro e do teste de transformação linfoblástica. Uma boa resposta linfoproliferativa a antigeno de Leishmania tem sido documentada em pacientes com várias formas da doença, tais como: lesão ulcerada isolada, lesão mucosa isolada, lesão cutâneo-mucosa e em casos isolados de formas menos comuns como lesōes disseminadas ou múltiplas 363796 . Do ponto de vista imunológico a documentação de uma resposta imune celular preservada na leishmaniose tegumentar é o marco mais importante de diferenciação desta forma de doença com a leishmaniose visceral, situação na qual existe supressão da resposta imune celular ${ }^{38}$.

Avaliando a resposta linfoproliferativa a antigeno de Leishmania em pacientes da Venezuela onde as cepas predominantes são do complexo $L$. mexicana e $L$. braziliensis, Castes e cols ${ }^{40}$ verificaram uma boa resposta proliferativa em todos os casos, bem como positividade no teste de hipersensibilidade de tipo tardio. Comparando os resultados de formas cutâneas com os observados em lesão mucosa, Castes e cols ${ }^{40}$ demonstraram que a resposta blastogênica nos pacientes com lesão mucosa era superior aos pacientes com lesão cutânea reforçando a possibilidade de que a lesão mucosa poderia representar uma reação de hipersensibilidade tardia ao parasita. Esta resposta exarcebada, segundo Castes e cols $^{39}$ estaria relacionada com uma diminuição da atividade de células supressoras em pacientes com leishmaniose mucosa. Como o quadro histológico habitualmente observado na forma mucosa da leishmania se caracteriza por uma presença de linfócitos e plasmócitos e ausência ou escassez de parasitas, a hipótese de que a leishmaniose mucosa represente o pólo de hipersensibilidade do hospedeiro permanece viável. Walton e cols ${ }^{153}$ analisando a patogênese destas lesões mucosas sugerem que além da exacerbação da resposta imune celular, outros fatores como a ocorrência concomitante de tuberculose ou desnutrição podem estar envolvidos na gênese da doença mucosa. Embora lesão mucosa possa representar uma lesão de hipersensibilidade ao parasita ou a antigenos do hospedeiro modificados pelo parasita, alguns dados contrários a esta hipótese devem ser salientados: 1) A resposta exacerbada observada em pacientes com lesão mucosa pode apenas refletir uma constante estimulação do sistema imune, desde que o parasita persista no hospedeiro por um longo periodo de tempo. 2) A observação de que havia diminuição de atividade supressora em pacientes com doença mucosa não foi comprovada em estudos posteriormente realizados ${ }^{140}$. 3) Lesões mucosas têm sido documentadas em pacientes com depressão da resposta celular a antigeno do parasita e com quadro histopatológico que não sugere hipersensibilidade ${ }^{124}$.
A possibilidade de que a imunidade humoral tenha participação na gênese das lesōes mucosas da leishmaniose não pode ser afastada. Títulos de anticorpos são mais elevados nas formas mucosas do que nas formas cutâneas ${ }^{48} \mathrm{e}$ complexos imunes circulantes são mais freqüentemente documentados e em titulos mais elevados na forma mucosa da doença ${ }^{52}$. Estes achados, juntamente com a observação de que as lesões mucosas contèm grande quantidade de plasmócitos e de imunoglobulinas ${ }^{110}$ abrem perspectivas para que estudos sejam desenvolvidos no sentido de avaliar a participação de componentes humorais no aparecimento destas lesões.

Estudando pacientes em uma área endêmica de L. braziliensis no Brasil tanto com lesões cutâneas como com lesões mucosas nós temos observado que na maioria dos pacientes os linfócitos apresentam transformação blastogênica quando estimulados com antígeno de Leishmania. Além disto, o número de linfócitos $\mathbf{T}$ e $\mathbf{B}$ é preservado em sangue periférico destes pacientes e uma boa resposta blastogênica e a mitógenos tem sido documentada ${ }^{37}$. Embora a avaliação imunológica "in vivo" e "in vitro" de pacientes com doença cutânea ou mucosa com evolução longa (> 2 meses) tenha este padrão homogêneo de resposta, caracterizado por reação de Montenegro positiva, resposta linfo-proliferativa preservada para antígeno $e$ mitógenos e ausência de alterações na população de linfócitos no sangue periférico ${ }^{37}$, quando os pacientes são avaliados na fase inicial da doença, menos de 2 meses de evolução clínica, pode ser documentada ausência de resposta blastogênica, teste intradérmico negativo e ausência de anticorpos específicos no soro. Uma depressão inicial da resposta imune na leishmaniose tegumentar tem sido observada também por outros autores. Por exemplo, estudando uma epidemia de leishmaniose cutânea na Venezuela, Lynch e cols ${ }^{93}$ observaram que o percentual de testes intradérmicos positivos era mais freqüente em individuos com mais de 60 dias de infecção. Mendonça e cols ${ }^{105}$ em uma área endêmica de $L$. braziliensis, têm identificado casos com testes intradérmicos negativos e ausência de resposta blastogênica, e pacientes com reação de Montenegro positiva mas ausência de transformação linfoblástica. Nesta casuística, uma boa correlação tem sido feita entre a resposta imunológica e a resposta terapêutica ${ }^{105}$. Ou seja, os pacientes que respondem a antigeno de Leishmania curam com mais facilidade, indicando a relevância da resposta imune no controle da doença.

A importância da presença ou não da resposta imune detectável em uma fase inicial da doença deve ser pesquisada. É possível que a incapacidade de detectar uma resposta imune eficaz logo após a infecção deva-se ao fato de que as células envolvidas na resposta imune aos antigenos parasitários estejam 
localizados no sítio da lesão. Não pode ser afastada, entretanto, a possibilidade de que a resposta deprimida represente uma predominância de células supressoras e que este fenômeno venha a ter implicaçōes na determinação da forma clinica a ser manifestada pelo paciente. Voorhis e cols ${ }^{150}$ documentaram que embora não exista diferença na distribuição de células auxiliadoras e supressoras no sangue periférico de pacientes com lepra lepromatosa e lepra tuberculóide, quando se analisa a distribuição celular na lesão, documenta-se que na lepra lepromatosa há um grande aumento de células supressoras nos tecidos. Estudando pacientes com lesão cutânea e comparando com lesão mucosa, Barral e cols ${ }^{14}$ (enviado para publicação) não encont: aram diferença significativa na população de células colaboradoras e supressoras nas duas formas da doença. Se faz necessário entretanto que estudos, avaliando a função das células envolvidas na lesão, sejam realizados para que se determine a existência ou não de diferença entre o que é observado no sangue ou o que ocorre nos tecidos.

Os estudos da respota imune na leishmaniose tegumentar americana são raros e na sua totalidade as avaliaçōes têm sido dirigidas basicamente para a função linfocitária e pouco se tem estudado a respeito dos macrófagos e da cooperação entre linfócitos e macrófagos. Este aspecto é de grande relevância desde que tanto em modelos experimentais como na espécie humana a Leishmania pode ser destruída por macrófagos quando estes são ativados por produtos de linfócitos T. Avaliando a interação de $L$. mexicana e macrófagos de individuos sadios, Carvalho e cols 37 documentaram que estes macrófagos podem destruir Leishmania quando a eles são adicionados sobrenadantes de cultura de linfócitos de pacientes com leishmaniose tegumentar. Estes achados demonstram que os linfócitos destes pacientes têm a capacidade de produzir linfocinas que ativam macrófagos o que está em concordancia com os achados recentes de que nestes sobrenadantes são encontrados niveis elevados de interferon gama ${ }^{37}$. Além da capacidade preservada da produção de linfocinas com atividade leishmanicida, macrófagos de pacientes com doença mucosa quando ativados por linfocinas inibem a multiplicação intracelular de Leishmania ${ }^{37}$. Estes dados demonstram que, baseados nos estudos até agora realizados, nem uma reação de hipersensibilidade nem um defeito nos mecanismos de defesa do hospedeiro se constituem explicaçōes convincentes para a ocorrência de lesões mucosas. A demonstração por outro lado da existência de cepas de Leishmania resistentes aos mecanismos de defesa do hospedeiro ${ }^{142}$ e resistentes a antimoniais ${ }^{20}$, aliado ao fato de que a resposta imune no sítio da lesão pode ser anormal, indica que além dos estudos da resposta imune do hospedeiro, mais se deve conhecer a respeito das cepas de parasitas causadores das diversas formas clinicas da doença, e dos mecanismos de defesa no sítio da lesão.

\section{IMUNODIAGNÓSTICO}

\section{TESTES SOROLÓGICOS}

Apesar das controvérsias na literatura a respeito da sensibilidade e especificidade das técnicas aplicadas ao imunodiagnóstico, a utilização de testes sorológicos e de intradermorreação ainda são os principais métodos usados para o diagnóstico da maioria das protozooses ${ }^{70}$. Na leishmaniose tegumentar de há muito que a sorologia e o teste cutâneo vêm sendo realizados 108111 . Diferentemente da leishmaniose visceral, na leishmaniose cutâneo-mucosa os anticorpos circulantes não estão em concentrações suficientemente elevadas, para permitirem que a realização dos testes sorológicos mais simples tais como precipitação em tubo, em gel de agar e formol-gel, tenham um alto percentual de positividade 2526 . Por isso, somente após o advento das novas técnicas de marcação (imunofluorescência e ensaios imunoenzimáticos) é que o papel dos anticorpos específicos anti-Leishmania tem sido melhor estudado $^{716}$. Das técnicas anteriormente utilizadas. a reação de fixação de complemento (RFC) e o teste de aglutinação direta merecem uma análise especial. Ainda hoje alguns centros continuam utilizando a RFC como método principal na detecção de anticorpos circulantes. É clássica a utilização da reação de Guerreiro Machado para o sorodiagnóstico da doença le Chagas 577 . Na leishmaniose tegumentar, Mose 111 relata que anticorpos foram detectados em todos os casos testados. Esses resultados não têm sido confirmados ao longo dos anos 132133 . Com o advento das novas técnicas de menor complexidade e variáveis biológicas, a RFC tem sido relegada ao passado no que se refere ao diagnóstico sorológico das leishmanioses.

$O$ teste de aglutinação direta (TAD) dado à sua simplicidade no preparo do antígeno e da sua realizaçào, tem sido ainda proposto. Allain e cols ${ }^{4}$ chamam atenção que a utilização de $L$. braziliensis como fonte de antígeno melhora muito a sensibilidade do teste. Embora os titulos sejam bem inferiores aos encontrados na leishmaniose visceral, de 61 pacientes com leishmaniose tegumentar testados 50 foram positivos com titulos $\geq 64$. Reatividade cruzada ocorre sobretudo com soros de pacientes portadores de tripanossomíases. Anticorpos da classe IgM são também detectados pelo TAD. A facilidade na execução e estabilidade dos reagentes ainda permitem a recomendação deste teste em áreas onde as novas técnicas não sejam disponíveis. Tem-se que considerar a elevada reatividade cruzada e que títulos significativos são considerados somente $\geq 32$. 
Nos anos 70, duas técnicas vêm sendo preferidas para deteç̧ão de anticorpos circulantes. A imunofluorescência indireta e os ensaios imunoenzimáticos, originalmente chamado de Enzyme Linked Immunosorbent Assay (Elisa) 305157149 .

Bray e Lainson ${ }^{30}$, em 1965, descreveram detalhadamente a reação de imunofluorescência indireta (RIFI), aplicada ao sorodiagnóstico da leishmaniose tegumentar. Os seus resultados não foram satisfatórios, visto que de 20 soros de leishmanióticos testados, franca positividade foi obtida somente em 12 destes $(60 \%)$, contrastando com $40 \%$ de positividade dos soros de pessoas não suspeitas de leishmaniose tegumentar. Em 1968, Bittencourt, Sodré e Andra$\mathrm{de}^{23}$, contrariando resultados anteriores encontraram $96 \%$ de positividade sorológica através de RIFI em 29 soros de pacientes leishmanióticos. Uma crítica aos seus resultados se faz a não diluição do soro no momento da realização do teste, bem como a reatividade cruzada com outras doenças endêmicas existentes nas localidades de onde provieram seus pacientes. Em 1972, Walton e cols ${ }^{151}$ chamam a atenção que o insucesso da reação de RIFI na leishmaniose tegumentar se deve ao fato da utilização de formas promastigotas de Leishmania como fonte de antígeno, visto que no parasitismo humano somente as formas amastigotas são encontradas. Seus resultados ratificam sua idéia; $28 / 30$ soros de pacientes com lesões cutâneas ativas de LT foram positivos com titulos variando entre 8-1024. Do mesmo modo 25/28 soros de pacientes com lesões de mucosa revelaram os mesmos resultados. A especificidade deste antigeno (formas amastigotas) foi de $\mathbf{9 3} \%$ incluindo soros de pacientes chagásico e de infecção por $T$. rangelli. Em contraposição, Guimarães e cols ${ }^{64}$, em 1974, propõem uma padronização de antigeno para RIFI para leishmaniose mucocutânea utilizando formas promastigotas de cultivos de 7 a 10 dias formolizadas a $2 \%$, visto que a obtenção de formas amastigotas em cultura de tecidos, como propõe Walton, nem sempre é possivel, além de ser bastante influenciada pela espécie e idade da cepa utilizada. Recentemente, Pappas 118 realizou um estudo comparativo entre o antígeno de promastigota e amastigota na RIFI. As formas amastigotas foram obtidas de 3 modos diferentes: cultivo "in vitro" em linhagem celular: isoladas de lesão de hamster infectado e transformação de promastigota em esferomastigota "in vitro" sob efeito da temperatura. Soro de 34 soldados portadores de leishmaniose cutânea foram avaliados. 28/34 $(82,4 \%)$ foram positivos com o antígeno de promastigota. Excetuando as amastigotas obtidas diretamente da lesão, a qual revelou resultados de positividade idêntica ao antigeno de promastigota: os 2 outros foram menos sensiveis. A média geométrica dos tutulos com promastigotas foi significantemente mais elevada do que com a amastigota. Não houve diferença significativa entre os antigenos com relação à reatividade cruzada e especificidade com relação aos soros de pessoas normais. Esses achados estão inteiramente em concordância com os resultados obtidos por Badaró, Reed e Carvalho ${ }^{10}$ em relato prévio comparando promastigotas e amastigotas como fonte de antígeno para a RIFI na leishmaniose visceral. Aliás, as promastigotas mostram uma sensibilidade e especificidade ligeiramente melhor do que as amastigotas. Por conseguinte recomenda-se a utilização de formas promastigotas como fonte de antígeno para a RIFI de preferência utilizando cepas homólogas e de cultivo entre o $7 \%^{\circ}-10 \%$ dias de crescimento, formolizada a $2 \%$. Títulos significativos devem ser considerados acima de 32.

Em 1972, com a introdução por Engvall Perlmann ${ }^{56}$ do método imunoenzimáticu na detecção de anticorpos circulantes, uma nova perspectiva técnica ficou disponivel para aplicação em imunodiagnóstico. Voller e cols ${ }^{149}$ ressaltam a grande aplicabilidade desta técnica de sorodiagnóstico das doenças parasitárias. Anthony e cols ${ }^{7}$ em 1980 propõem o método de Micro-Elisa (Micro Enzyme Linked Immunosorbent Assay) para o sorodiagnóstico da leishmaniose do Novo Mundo. Chama a atenção a comparabilidade desta técnica com a reação de imunofluorescência, além da possibilidade da utilização de extratos solúveis de Leishmania como fonte de antigeno. De 21 soros de leishmarrióticos testados, 16 foram positivos. Ressalta o autor a correlação entre o número de lesões e a positividade do teste. Semelhante ao que ocorre na reação da imunofluorescência, a utilização de formas amastigotas como fonte de antígeno não melhora os resultados. Roffi e cols ${ }^{135}$ reafirmam esses resultados enfatizando a sensibilidade do teste; $32 / 33$ (97\%) soros de pacientes com lesōes exclusivamente cutâneas e $3 / 3(100 \%)$ daquelas com lesões cutâneomucosas foram positivos. Do mesmo modo que a RIFI a especificidade do teste parece crítica com os extratos antigênicos atualmente utilizados. Sobretudo, com relação à reatividade cruzada com soros de portadores de tripanossomiases. Em ambos os trabalhos referidos esta reatividade foi superior a $70 \%$. De qualquer maneira esta parece ser a única técnica na atualidade, de fácil execução que permite a utilização de fração antigênica espécie-especifica para o sorodiagnóstico. Algumas formas clinicas da leishmaniose tegumentar se correlacionam com espécies bem definidas de Leishmania: o desenvolvimento de antigenos espécieespecifico ${ }^{104}$ poderia permitir a identificação por método sorológico de tais apresentações clinicas.

Vários aspectos ainda precisam ser padronizados no teste de Elisa. Por exemplo, as absorvâncias consideradas positivas, os conjugados enzimáticos e a diluição de soro ainda não foram criteriosamente 
analisados. Em nossa experiência a média de absorvância de soro de individuos sadios de 96 pessoas testadas foi de $0.026 \pm 0.007$ e de 30 soros leishmanióticos foi de $0.18 \pm 1.12$ em leitura espectrofotométrica com filtro de $405 \mathrm{~nm}$ a uma diluição de $1 / 100$, utilizando conjugado de fosfatase alcalina ${ }^{10}$. Já Roffi ${ }^{135}$ tem uma média de absorbância nos soros de individuos sadios entre 0,26 e 0,30 e dos soros leishmanióticos na absorbância de $0,56 \pm 0,15$. Embora o conjugado utilizado seja com a enzima peroxidase a leitura espectrofotométrica foi realizada no mesmo comprimento de onda $400 \mathrm{~nm}$.

Mais recentemente anti-soros especificos contra imunoglobulinas $\mathbf{G}, \mathbf{M}, \mathbf{A}$ e $\mathrm{E}$, têm sido utilizados numa tentativa de correlacionar títulos de anticorpos das diferentes classes de imunoglobulina com o prognóstico desta doença ${ }^{2}{ }^{143}$. A despeito da pequena casuística utilizada e da pouca consistência dos dados, é sugerido que pacientes com doença muco-cutânea têm niveis mais elevados de IgA e que ausência de lesão mucosa se associa com IgE circulante.

Por conseguinte, o estado atual dos testes sorológicos para leishmaniose tegumentar indicam que a determinação de anticorpos circulantes auxiliam no diagnóstico diferencial das ulceraçōes cutâneo-mucosas, sendo que preferentemente técnicas que possibilitam a caracterização do anticorpo especifico presentes, tais como a imunofluorescência e as técnicas de Elisa, devem ser escolhidas para o procedimento da rotina.

\section{TESTES INTRADERMICOS}

Montenegro108, em 1926, utilizou extrato bruto de $L$. braziliensis para avaliar a resposta ao teste de hipersensibilidade tardia ao antigeno de Leishmania, concluindo ser este método extremamente valioso para o diagnóstico de pacientes com ulcerações cutâneo-mucosas provocadas por protozoários do gênero Leishmania. Posteriormente, vários outros autores renovaram esta mesma impressão 124658123138 . Entretanto, é impressionante a variação das soluções antigênicas utilizadas para a realização destes testes intradérmicos. Desde promastigotas mortas e intactas em formalina ou em soluções mertiolatadas contendo $5 \times 10^{6}$ promastigotas por $\mathrm{ml}^{138}$ até extratos de antígenos brutos e/ou frações polissacarídicas especiais $^{4} 125$. Mais tarde, Rotberg ${ }^{136}$ chama atenção que concentrasios mass devadas dos parasitos intractos $\left(10^{7}\right.$ promastigotas $\left./ \mathrm{ml}\right)$ melhoram a positividade do teste. Entretanto, a utilização das formas intactas como antígeno não permite uma padronização de doses inoculadas de um paciente para outro, além de impossibilitar a definição exata da fração antigênica ativa, responsável pela cutis-reação. Já o próprio Montenegro inicialmente utilizou um extrato de Leishmania como fonte de antígeno para a intra- dermorreação por ele preconizada. Melo e cols ${ }^{106}$, em 1977, sugerem uma padronização do antígeno de Montenegro para uma concentração de $40 \mu \mathrm{g} \mathrm{N} / \mathrm{ml}$ da suspensão de um macerado de $L$. braziliensis através de ultrasonificação. Nesta concentração a positividade do teste foi de $96 \%$ quando 100 pacientes portadores de LTB foram testados. Uma sensibilidade similar de $94 \%$ foi relatada por Cuba Cuba ${ }^{50}$ em 56 pacientes leishmanióticos, embora de 24 pacientes parasitologicamente confirmados 3 foram negativos. Apesar da alta sensibilidade deste antígeno, continuamos ainda com uma indefinição da fração antigenicamente ativa responsável pela cutis-reaçāo, além da limitação da utilização de uma suspensão que é passível de variação na quantidade de antígeno injetado de um paciente para outro. Uma tentativa inicial de utilização de uma fração antigênica definida, foi realizada por Furtado e Pellegrino ${ }^{58}$, os quais utilizaram um extrato solúvel de Leishmania, contendo uma fração polissacarídica. Entretanto, seus resultados não foram muito animadores.

Recentemente, Reed e cols ${ }^{128}$ preconizaram um antigeno solúvel extraido de promastigotas mortas de $L$. mexicana amazonensis e outro de $L$. donovani chagasi, para utilização do teste de Montenegro de modo homólogo em pacientes leishmanióticos. O antigeno de $L$. mexicana amazonensis, quando foi testado na área endêmica de leishmaniose tegumentar na Bahia (Três Braços), reagiu em $100 \%$ de 50 pacientes portadores de lesões cutâneo-mucosas ativas e em $87 \%$ de 166 pessoas residentes na área endêmica com história e cicatriz leishmaniótica de até 20 anos de ocorrência ${ }^{76}$. Estes dados contrariam os resultados encontrados por Mayrink e cols ${ }^{103}$, os quais relatam somente $48 \%$ de positividade do teste de Montenegro em pacientes pós-tratamento. Ao nosso ver, o antígeno utilizado por Reed e cols ${ }^{131}$ parece ser mais estável, devido à utilização de uma banda glicoprotéica, que pode ser separada à centrifugação a $40,000 \mathrm{~g} 4{ }^{\circ} \mathrm{C}$. Outro aspecto técnico de real importância foi a utilização de Tween 80 para uma concentração final de $0,0005 \%$ (peso/volume), preservado a solução com fenol a $0,28 \%$ (peso/volume). Este procedimento para estabilização das glicoproteínas para utilização em antígenos para cutis-reação já é utilizado rotineiramente na preparação do PPD $^{82}$.

Ar sensiólistabe do resue de monnenegro parece estar relacionada com a dose de antigeno injetada no paciente. Recentemente Cuba Cuba e cols ${ }^{49}$ compararam a sensibilidade do teste de Montenegro utilizando concentrações diferentes de um extrato antigênico $(30 ; 9,6$ e $3 \mu \mathrm{gN})$ por dose injetada. Dos 30 pacientes com lesão ativa, $26(87 \%)$ responderam à dose $3 \mu \mathrm{g}, 29(97 \%)$ à dose de $9,6 \mu \mathrm{g}$ e todos responderam à dose de $30 \mu \mathrm{g}$. Em 41 pacientes com 
cicatriz pós-leishmaniose, $27(68 \%)$ responderam à $3 \mu \mathrm{g}, 34(83 \%)$ à $9,6 \mu \mathrm{g}$ e $40(98 \%)$ à $30 \mu \mathrm{g}$. No entretanto, reações indesejáveis, tipo formação de flictina com necrose ocorreu em $10 \%$ dos pacientes com lesões ativas e $17 \%$ no grupo de cicatrizes. Por esta razão este recomendou a dose de $9,6 \mu \mathrm{g}$ para a realização do teste. Reações falso-positivas, não têm sido referidas e todos os pacientes chagásicos testados foram negativos em todas as casuísticas estudadas.

Por conseguinte, o clássico teste de Montenegro se constitui um importante e fácil método de diagnóstico na leishmaniose tegumentar. $O$ antigeno solúvel $\mathrm{e}$ estabilizado com Tween 80 é facilmente conservado a $4^{\circ} \mathrm{C}$ e doses entre 40 e $30 \mu \mathrm{g}$ de proteina ou nitrogènio protéico de extrato de Leishmania podem ser escolhidas para a realização do teste na rotina diagnóstica.

\section{REFERÊNCIAS BIBLIOGRÁFICAS}

1. Adler S. Immunology of leishmaniasis. Israeli Journal of Medical Science 1: 9-13, 1965.

2. Afchain, D, Desjeux P, la Fuente C, Le Ray D, Cesbron, JY, Neyrinck JL, Capron A. Specific IgE antibodies to Leishmania braziliensis in patients with mucocutaneous leishmaniasis. Annales d'Immunologie (Institut Pasteur) 134c: 311-319, 1983.

3. Alexander J. Effect of the antiphagocytic agent cytochalasin B on macrophage invasion by Leishmania mexicana promastigotes and Trypanosoma cruzi promastigotes. Journal of Protozoology 22: 237-240, 1975.

4. Allain D, Kagan IG. A direct agglutination test for leishmaniasis. American Journal of Tropical Medicine and Hygiene 24: 232-236, 1975.

5. Almeida JWR, Camargo ME, Amato-Neto V. Comportamento evolutivo da reação de fixação do complemento quantitativo na fase crónica da doença de Chagas, sem influência do tratamento específico. Revista do Instituto de Medicina Tropical de São Paulo 22: 78-81 1980.

6. Andrade ZA, Reed SG, Roters SB, Sadigursky M. Patogenia da leishmaniose cutânea experimental. A importância da necrose na eliminação dos parasitas das lesões. Revista da Sociedade Brasileira de Medicina Tropical 17: 187-197, 1984.

7. Anthony RL, Christensen HA, Johnson CM. Micro enzyme-linked immunosorbent assay (ELISA) for the serodiagnosis of New World leishmaniasis. American Journal of Tropical Medicine and Hygiene 29: 190194, 1980.

8. Armstrong JA, Hart PD. Response of cultured macrophages to Mycobacterium tuberculosis with observations on fusion of lysosomes with phagosomes. Journal of Experimental Medicine 134: 713-740, 1971

9. Avila JL, Biondo F, Monzón H, Convit J. Cutaneous leishmaniasis on mice: Resistance to glucan immunotherapy, either alone or combined with chemotherapy. American Journal of Tropical Medicine and Hygiene 31: 53-59, 1982.
10. Badaró R, Reed SG, Barral A, Orge G, Jones TC. Evaluation of the micro enzyme-linked immunosorbent assay (Elisa) for antibodies to American visceral leishmaniasis: Standardization of parasite antigen to detect infection specific responses. American Journal of Tropical Medicine and Hygiene 35: 72-78, 1986.

11. Badaró R, Reed SG, Carvalho EM. Immunofluorescent antibody test in American visceral leishmaniasis: sensitivity and specificity of different morphological forms of two leishmania species. American Journal of Tropical Medicine and Hygiene 32: 430-484, 1983.

12. Barbosa W, Souza MCL, Rassi DM, Oliveira RL, Mota L. Investigação sobre imunologia da leishmaniose tegumentar americana. I. Intradermo-reação de Montenegro com antígeno de Leptomonas pessoai e $L$. braziliensis. Revista de Patologia Tropical 3: 377.383, 1972.

13. Barral A, Petersen EA, Sacks DL, Neva FA. Late metastatic leishmaniasis in the mouse. A model for mucocutaneous disease. American Journa! of Tropical Medicine and Hygiene 32: 277-285, 1983.

14. Barral A, Ribeiro de Jesus A, Almeida RP, Carvalho EM Barral-Netto M, Costa JML, Badaró R, Rocha $H$, Johnson WD. Evaluation of $T$ cell subsets in the lesion infiltrates of human cutaneous and mucocutaneous leishmaniasis. (Enviado para publicação).

15. Barral-Netto M, Roters SB, Barral AP. Interleukin-2 production during murine infection by Leishmania mexicana amazonensis. Memórias do Instituto Oswaldo Cruz 81: 43-47, 1986.

16. Behforuz N, Rezai HR, Gettner S. Application of immunofluorescence for detection of antibody in Leishmania infections. Annals of Tropical Medicine and Parasitology 70: 293-301, 1976.

17. Behin R, Mauel J, Biroum-Noerjasin, Rowe, DS. Mechanisms of protective immunity in experimental cutaneous leishmaniasis of the guinea-ping. II Selective destruction of different Leishmania species in activated guinea-ping and mouse macrophages. Clinical and Experimental Immunology 20: 351-358, 1975.

18. Behin R, Mauel J, Rowe DS. Mechanisms of protective immunity in experimental cutaneous leishmaniasis in the guinea ping. III. Inhibition of leishmanial lesion in the guinea-pig of delayed hypersensitivity reaction tc related antigens. Clinical and Experimental Immunology 29: 320-325, 1977.

19. Behin R, Mauel J, Sordat B. Leishmania tropica: pathogenicity and in vitro macrophage function in strains of inbred mice. Experimental Parasitology 48: 81-91, 1979.

20. Berman JP. In vitro susceptibility of antimony-resistant Leishmania to alternative drugs. Journal of Infectious Disease 145: 279, 1982.

21. Berman JD, Dwyer DM. Expression of Leishmania antigen on the surface membrane of infected human macrophages in vitro. Clinical and Experimental Immunology 44: 342-348, 1981.

22. Bittencourt AL, Andrade ZA. Aspectos imunopatológicos na leishmaniose cutâneo-mucosa. O Hospital $71: 89-98,1967$. 
23. Bittencourt A, Sodré A, Andrade Z. Pesquisa de anticorpos circulantes pelo método de imunofluorescência na leishmaniose tegumentar. Revista do Instituto de Medicina Tropical de São Paulo 10: 247 $252,1968$.

24. Bradley DJ. Genetic control of natural resistance to Leishmania donovani. Nature (London) 250: 353354, 1974.

25. Bray RS. Immunodiagnosis of leishmaniasis. In: Cohen S, Sadun E (eds). Immunology of parasitic infections. Blackwell Scientific Publication, Oxford, p. $65-76,1976$.

26. Bray RS. Leishmaniasis. In: Houba V.(ed). Immunological investigation of tropical parasitic diseases. Churchill Livingstone, London, 65-74, 1980.

27. Bray RS. Leishmania mexicana mexicana: Attachment and uptake of promastigotes to and by macrophages in vitro. Journal of Protozoology 30: 314-322, 1983.

28. Bray RS. Leishmania: chemotaxic responses of promastigotes and macrophages in vitro. Journal of Protozoology 30: 322-329, 1983.

29. Bray RS, Heikal B, Kaye PM, Bray MA. The effect of parasitization by Leishmania mexicana mexicana on macrophage function in vitro. Acta Tropica 40: 2938, 1983.

30. Bray RS, Lainson R. The immunology and serology of leishmaniasis. I. The fluorescent antibody staining technique. Transactions of the Royal Society of Tropical Medicine and Hygiene 59: 535-544, 1965.

31. Bryceson ADM. Diffuse cutaneous leishmaniasis in Ethiopia. I. The clinical and histological features of the disease. Transactions of the Royal Society of Tropical Medicine and Hygiene 63: 708-737, 1969.

32. Bryceson ADM. Immunological aspects of clinical leishmaniasis. Proceedings of the Royal Society of Medicine 63: 40-44, 1970.

33. Bryceson ADM. Diffuse cutaneous leishmaniasis in Ethiopia. III. Immunological studies. Transactions of the Royal Society of Tropical Medicine and Hygiene 64: 380-387, 1970.

34. Bryceson ADM, Bray RS, Wolstencroft RA, Dumonde DC. Immunity in cutaneous leishmaniasis of the guineapig. Clinical and Experimental Immuno$\operatorname{logy} 7: 301-341,1970$.

35. Bryceson ADM, Preston PM, Bray RS, Dumonde DC. Experimental cutaneous leishmaniasis. II. Effects of immunosuppression and antigenic competition on the course of infection with Leishmania enrietti in the guinea-pig. Clinical and Experimental Immunology 10: 305-335, 1972.

36. Carvalho EM, Barreto AC, Badaró $\mathbf{R}$, Marsden $\mathbf{P}$, Barral A, Cuba Cuba C, Rocha H. Avaliaçāo imunológica em pacientes com leishmania tegumentar. In: Resumos da X Reunião Anual de Pesquisa Básica em Doença de Chagas, p. 8, 1983.

37. Carvalho EM, Johnson WD, Barreto E, Marsden PD, Costa JLM, Reed S, Rocha H. Cell-mediated immunity in American cutaneous and mucocutaneous leishmaniasis. Journal of Immunology 135: 41444149, 1985.

38. Carvalho EM, Teixeira RS, Johnson WD. Cell- mediated immunity in American visceral leishmaniasis. Reversible immunosuppression during acute infection. Infection and Immunity 22: 649-656, 1981.

39. Castes M, Agnelli A, Rondon AJ. Mechanisms associated with immunoregulation in human American cutaneous leishmaniasis. Clinical and Experimental Immunology 57: 279-286, 1984.

40. Castes M, Agnelli A, Verde O, Rondon AJ. Characterization of the cellular immune response in American cutaneous leishmaniasis. Clinical Immunology and Immunopathology 27: 176-186, 1983.

41. Chang KP. Leishmania infection of human skin fibroblasts in vitro: absence of phagolysosomal fusion after induced phagocytosis of promastigotes and their intracellular transformation. American Journal of Tropical Medicine and Hygiene 27: 1084-1096, 1978.

42. Chang KP. Leishmania donovani: promastigotemacrophage surface interaction in vitro. Experimental Parasitology 48: 175-189, 1979.

43. Chang KP. Antibody-mediated inhibition of phagocytosis in Leishmania donovani-human phagocyte interaction in vitro. American Journal of Tropical Medicine and Hygiene 30: 334-339, 1981.

44. Chang, KP, Dwyer DM. Leishmania donovanihamster macrophage interactions in vitro: cell entry, intracellular survival, and multiplication of amastigotes. Journal of Experimental Medicine 147: 515 $530,1978$.

45. Colle JH, Truffa-Bachi P, Chedid L, Modabber F. Lack of general immunosuppression during visceral Leishmania tropica infection in $\mathrm{Balb} / \mathrm{c}$ mice: augmented antibody response to thymus-independent antigens and polyclonal activation. Journal of Immunology 131: 1492-1495, 1983.

46. Corrêa MOA, Amato-Neto V. Intradermorreações com antigeno de culturas de Leishmania braziliensis submetidas à ação do ultrasom. Revista do Instituto Adolfo Lutz 17:39-42, 1957.

47. Coutinho SG, Louis J, Mauel J, Engers HD. Induction by specific $\mathrm{T}$ lymphocytes of intracellular destruction of Leishmania tropica major in infected immune macrophages. Parasite Immunology 6: 157 . 169,1984

48. Cuba CC, L Lanos-Cuentas EA, Barreto AC, Magalhães AV, Lago EL, Reed SG, Marsden PD. Leishmaniose mucocutânea humana em Très Braços, Bahia, Brasil, Uma área de transmissão de Leishmania braziliensis braziliensis. I. Diagnóstico laboratorial. Revista da Sociedade Brasileira de Medicina Tropical 17: 161-167, 1984.

49. Cuba Cuba CA, Marsden PD, Barreto AC, Jones TC, Richards $F$. The use of different concentrations of leishmanial antigen in skin testing to evaluate delayed hypersensitivity in American cutaneous leishmaniasis. Revista da Sociedade Brasileira de Medicina Tropical 18: 231-236, 1985

50. Cuba Cuba AC, Marsden PD, Barreto AC, Rocha R, Sampaio RR, Patzlaff L. Diagnóstico parasitológico e imunologico de leishmaniasis tegumentaria americana. Boletin de la Oficina Sanitaria Panamericana 89: 195-208, 1980. 
51. Dedet JP, Ryter A, Vogt E, Hosli P, Silva LP. Uptake and killing of Leishmania mexicana amazonensis amastigotes by human skin fibroblasts. Annals of Tropical Medicine and Parasitology 77: 35-44, 1983.

52. Desjeux $P$, Santoro F, Afchain D, Lovens $M$, Capron A. Circulating immune complexes and anti-IgG antibodies in mucocutaneous leishmaniasis. American Journal of Tropical Medicine and Hygiene 29: 195-198, 1980.

53. Dwyer DM. Antibody-induced modulation of Leishmania donovani surface membrane antigens. Journal of Immunology 117: 2081-2091, 1976.

54. Dwyer DH. Leishmania donovani: Surface membrane carbohydrates of promastigotes. Experimental Parasitology 41: 341-358, 1977.

55. Dwyer DM, Langreth SG, Dwyer NK. Evidence for a polysaccharide surface coat in the development stages of Leishmania donovani: a fine structure-cytochemical study. Zeitschrift für Parasitenkunden 43: 227 249, 1974.

56. Engvall E, Perlmann P. Initial enzyme-linked immunosorbent assay (Elisa). III. Quantitation of specific antibodies by enzyme labelled anti-globulin in antigen coated tubes. Journal of Immunology 109: 129-135, 1972.

57. Faulk WP, Humans W. Recent developments in immunofluorescence. Progress in Allergy 16: 9-39, 1972.

58. Furtado TA, Pellegrino J. Intradermal test in American leishmaniasis with a polysaccharide fraction isolated from Leishmania braziliensis. Journal of Investigative Dermatology 27: 53-59, 1956.

59. Gorczynski RM, MacRae S. Analysis of subpopulations of glass-adherent mouse skin cells controlling resistance/susceptibility to infection with Leishmania tropica, and correlation with the development of independent proliferative signals to Lyt-1 ${ }^{+} / \mathrm{Lyt}-2^{+} \mathrm{T}$ lymphocytes. Cellular Immunology 67: 74-89, 1982.

60. Gottlieb M, Dwyer DM. Protozoan parasites of humans: surface membrane with externally disposed acid phosphatase. Science 212: 939-941, 1981.

61. Grimaldi Jr G. Leishmanioses tegumentares: Aspectos clínicos e imunopatológicos. Memórias do Instituto Oswaldo Cruz 77: 195-215, 1982.

62. Grimaldi GF, Moriearty PL, Hoff R. Leishmania mexicana in $\mathrm{C} 3 \mathrm{H}$ mice: $\mathrm{BCG}$ and levamisole treatment of established infections. Clinical and Experimental Immunology, 41: 237-242, 1980.

63. Grimaldi Jr G, Soares MJ, Moriearty PL. Tissue eosinophilia and Leishmania mexicana mexicana eosinophil interactions in murine cutaneous leishmaniasis. Parasite Immunology 6: 397-408, 1984.

64. Guimarães MCS, Giovannini VL, Camargo ME. Antigenic standardization for mucocutaneous leishmaniasis immunofluorescence test. Revista do Instituto de Medicina Tropical de São Paulo 16: 145-148, 1974.

65. Hale C, Howard JG. Immunological regulation of experimental cutaneous leishmaniasis. II. Studies with Biozzi high and low responder mice. Parasite Immunology 3: 45-55, 1981.

66. Handman E, Burgess AW. Stimulation by granulocyte-macrophage colony-stimulating factor of
Leishmania tropica killing by macrophages. Journal of Immunology 122: 1134-1137, 1979.

67. Handman E, Ceredig R, Mitchelle GF. Murine cutaneous leishmaniasis: disease patterns in intact and nude mice of various genotypes and examination of some differences between normal and infected macrophages. Australian Journal of Experimental Biology and Medical Sciences 57: 9-29, 1979.

68. Herman R. Cytophilic and opsonic antibodies in visceral leishmaniasis in mice. Infection and Immunity 28: 585-593, 1980.

69. Hill JO. Resistance to cutaneous leishmaniasis: Acquired ability of the host to kill parasites at the site of infection. Infection and Immunity 45: 127-132, 1984.

70. Houba V. Introduction in Houba V (ed.). Immunological investigation of tropical parasitic disease. Churchill Livingstone, London, 1980.

71. Howard JG, Hale C, Chan-Liew WL. Immunological regulation of experimental cutaneous leishmaniasis. I. Immunogenetic aspects of susceptibility to Leishmania tropica in mice. Parasite Immunology 2: 303$314,1980$.

72. Howard JG, Hale C, Liew FY. Immunological regulation of experimental cutaneous leishmaniasis. III. The nature and significance of specific supression of cell-mediated immunity. Journal of Experimental Medicine 152: 594-607, 1980.

73. Howard JG, Hale C, Liew FY. Immunological regulation of experimental cutaneous leishmaniasis. IV. Prophylactic effect of sub-lethal iradiation as a result of abrogation of suppressor $\mathrm{T}$-cell generation in mice genetically susceptible to Leishmania tropica. Joumal of Experimental Medicine 153: 557-568, 1981.

74. Howard JG, Liew FY, Hale C, Nicklin S. Prophylactic immunization against experimental leishmaniasis. II. Further characterization of the protective immunity against fatal Leishmania tropica infection induced by irradiated promastigotes. Journal of Immunology 132: 450-455, 1984.

75. Jones TC, Hirsch JG. The interaction between Toxoplasma gondii and mammalian cells. II. The absence of lysosomal fusion with phagocytic vacuoles containing living parasites. Journal of Experimental Medicine 136: 1173-1194, 1972.

76. Jones TC, Johnson WDJr, Barreto A, Badaró R, Cerf B, Reed SG, Neto EM, Tada MS, França F, Weise K, Golightly L, Fikrik E, Costa JMM, Cuba Cuba C, Marsden PD. Epidemiology and clinical manifestation of American cutaneous leishmaniasis due to Leishmania braziliensis. (Enviado para publicação).

77. Kagan IG. American trypanosomiaşis (Chagas' disease) In: Houba V. (ed.). Immunological investigation of tropical parasitic diseases. Churchill Livingstone, London, 49-64, 1980.

78. Kirkpatrick CE, Farrel JP. Splenik natural killer cell mice. Infection and Immunity 38: 1208-1216, 1982.

79. Kirkpatrick CE, Farrel JP. Splenic natural killer cell activity in mice infected with $L$. donovani. Cellular Immunology 85: 201-214, 1984. 
80. Klempner MS, Cendron M, Wyler DJ. Attachment of plasma membrane vesicles of human macrophages to Leishmania tropica promastigotes. Journal of Infectious Diseases 148: 377-384, 1983.

81. Kress Y, Tanowitz H, Bloom B, Wittner M. Trypanosoma cruzi: Infection of normal and activated mouse macrophages. Experimental Parasitology 41: 385-396, 1977.

82. Landi S, Held HR, Tseng MD. Disparity of potency between stabilized and nonstabilized dilute tuberculin solution. American Review of Respiratory Diseases 104: 385-393, 1971.

83. Leclerc C, Modabber F, Deriaud E, Djoko-Tamnou J, Chedid L. Visceral Leishmania tropica infection of Balb/c mice: cellular analysis of in vitro unresponsiveness to sheep erythrocytes. Infection and Immunity 37: 895-902, 1982.

84. Lewis DH. Infection of tissue culture cells of low phagocytic ability by Leishmania mexicana mexicana. Annals of Tropical Medicine and Parasitology 68: 327-336, 1974

85. Lewis DH, Peters W. The resistance of intracellular Leishmania parasites to digestion by lysosomal enzymes. Annals of Tropical Medicine and Parasitology 71: 295-312, 1977.

86. Liew FY. Specific suppression of responses to Leishmania tropica by a cloned T-cell line. Nature 305: 630-632, 1983.

87. Lima GMCA. Leishmania-specific murine T-cell lines and clones: Functional analysis in vitro and in vivo. Ph. D Thesis. (Docteur ès Sciences). Faculté des Sciences de l'Université de Lausanne, 1983.

88. Lima GC, Engers HD, Louis JA. Adoptive transfer of delayed type hypersensitivity reactions specific for Leishmania major antigens to normal mice using murine T-cell populations and clones generated in vitro. Clinical and Experimental Immunology 57:130-138, 1984.

89. Llanos-Cuentas EA. Estudo clínico evolutivo da leishmaniose em área endêmica de Leishmania braziliensis braziliensis, Três Braços, Bahia. Tese de Mestrado, Universidade de Brasilia, 1984.

90. Llanos-Cuentas EA, Marsden PD, Cuba CC, Barreto AC, Campos M. Possible risk factors in development of mucosal lesions in leishmaniasis. Lancet 2: 195, 1984.

91. Louis JA, Moedder E, Behin R, Engers H. Recognition of protozoan parasite antigens by murine $T$ lymphocytes. I. Induction of specific T-lymphocytedependent proliferative response to Leishmania tropica. European Journal of Immunology 9: 841 $847,1979$.

92. Louis JA, Zubler RH, Coutinho SG, Lima G, Behin $\mathrm{R}$, Mauel J, Engers HD. The in vitro generation and functional analysis of murine $T$-cell populations and clones specific for the protozoan parasite, Leishmania tropica. Immunological Reviews 61:215-243, 1982.

93. Lynch NR, Yarzabal L, Verde O, Avila JL, Monzon H, Convit J. Delayed type hypersensitivity and immunoglobulin $\mathrm{E}$ in American cutaneous leishmaniasis. Infection and Immunity 38: 877-881, 1982.
94. Magalhães AV. Histopatologia da leishmaniose tegumentar de Três Braços, Bahia. Tese de Doutoramento. Belo Horizonte, Minas Gerais, 1984.

95. Magalhães AV, Chiarini LH, Raick AN. Histopatologia da leishmaniose tegumentar. Revista do Instituto de Medicina Tropical de São Paulo 24: 268276, 1982.

96. Marsden PD. Clinical presentations of Leishmania braziliensis braziliensis. Parasitology Today 1: 129133, 1985.

97. Marsden PD, Llanos-Cuentas EA, Lago EL, Cuba CC, Barreto AC, Costa JM, Jones TC. Leishmaniose mucocutânea humana em Três Braços, Bahia-Brasil. Uma área de transmissão de Leishmania braziliensis braziliensis. III. Comprometimento mucoso e evolução inicial. Revista da Sociedade Brasileira de Medicina Tropical 17: 179-186, 1984.

98. Mauel J. The biology of the macrophage-Leishmania interaction. The Host Invader Interplay. H. Van den Bossche (ed.) Elsevier/North-Holland Biomedical Press, Amsterdam, 1980.

99. Mauel J. Recent advances in the immunology of leishmanial infections (with particular reference to the problem of vaccination). Pontificiae Academiae Scientiarum Scripta Varia 47: 91-112, 1982.

100. Mauel J, Behin R. Cell-mediated and humoral immunity to protozoan infections with special reference to leishmaniasis. Transplantation Review 19: 121-146, 1974.

101. Mauel J, Behin R, Biroum-Noerjasin N, Rowe DS. Mechanisms of protective immunity in the guinea-pig. I. Lack of effects of immune lymphocytes and of activated macrophages. Clinical and Experimental Immunology 20: 339-350, 1975.

102. Mauel J, Buchmuller Y, Behin R. Studies on the mechanisms of macrophage activation. I. Destruction of intra cellular Leishmania enrietti in macrophages activated by coculfivation with stimulated lymphocytes. Journal of Experimental Medicine 148: 393407, 1978.

103. Mayrink W, Melo MN, Costa CA, Magalhães PA, Dias M, Coelho MV, Araújo FG, Williams P, Figueiredo Batista SM. Intradermorreação de Montenegro na leishmaniose tegumentar americana após terapêtica antimonial. Revista do Instituto de $\mathbf{M e -}$ dicina Tropical de São Paulo 18: 182-185, 1976.

104. McMahon-Pratt D, Bennett E, David J. Monoclonal antibodies that distinguish subspecies of Leishmania braziliensis. Journal of Immunology 129: 929-937, 1982.

105. Mendonça SC, Amerdoura RR, Marzochi MCA, Pirmez C, Coutinho SG. Human American cutaneous leishmaniasis (Leishmania b. braziliensis) in Brazil. Lymphoproliferative response - Influence of therapy. Clinical and Experimental Immunology 64: 269-276, 1986.

106. Melo MN, Mayrink W, Costa CA, Magalhães PA, Dias M, Williams P, Araújo FG, Coelho M, Batista SM. Padronização do antígeno de Montenegro. Revista do Instituto de Medicina Tropical de São Paulo 19: 161-164, 1977. 
Revisão. Barral-Netto M, Badaró R, Barral A, Carvalho EM. Imunologia da leishmaniose tegumentar. Revista da Sociedade

107. Merino F, Ajjam E, Hernández A, Dawidowicz K, Merino EJ. In vitro infection of murine macrophages by Leishmania braziliensis. Mechanisms of penetration. International Archives of Allergy and Applied Immunology 55: 487-495, 1977.

108. Montenegro J. Cutaneous reaction in leishmaniasis. Archives of Dermatology and Syphilography 13: 187-194, 1926.

109. Moriearty PL, Bittencourt AL, Pereira C, Teixeira R, Barreto E, Guimarães NA. Borderline cutaneous leishmaniasis. Clinical, immunological and histological differences from mucocutaneous leishmaniasis. Revista do Instituto de Medicina Tropical de São Paulo 20: 15-21, 1978.

110. Moriearty PL, Grimaldi G, Galvão-Castro B, Oliveira Neto MP, Marzochi MCA. Intralesional plasma cells and serological responses in human cutaneous leishmaniasis. Clinical and Experimental Immunology 47: 59-64, 1982.

111. Moses A. Da fixação de complemento na leishmaniose tegumentar. Brasil Médico: 107-108, 1919.

112. Murray HW. Susceptibility of Leishmania to oxygen intermediates and killing by normal macrophages. Journal of Experimental Medicine 153: 1302-1315, 1981.

113. Murray HW. Cell-mediated immune response in experimental visceral leishmaniasis. II. Oxygen-dependent killing of intracellular Leishmania donovani amastigotes. Journal of Immunology 129: 351-357, 1982.

114. Murray HW, Masur H, Keithly JS. Cell-mediated immune response in experimental visceral leishmaniasis. I. Correlation between resistance to Leishmania donovani and lymphokine-generating capacity. Journal of Immunology 129: 344-350, 1982.

115. Nacy CA, Fortier AH, Pappas MG, Henry RR. Susceptibility of inbred mice to Leishmania tropica infection: correlation of susceptibility with in vitro defective macrophage microbicidal activities. Cellular Immunology 77: 298-307, 1983.

116. Nacy CA, James SL, Benjamin WR, Farrar JJ, Hockmeyer WT, Meltzer MS. Activation of macrophages for microbicidal and tumoricidal effector functions by soluble factors from EL-4, a continuous cell line. Infection and Immunity 40: 820-824, 1983.

117. Nacy CA, Meltzer MS, Leonard EJ, Wyler DJ. Intracellular replication and lymphokine-induced destruction of Leishmania tropica in $\mathrm{C} 3 \mathrm{H} / \mathrm{HeN}$ mouse macrophages. Journal of Immunology 127: 2381-2386, 1981.

118. Pappas MG, McGreevy PB, Hajakowski R, Hendricks LD, Oster CN, Hockmeyer WT. Evaluation of promastigote and amastigote antigens in the indirect fluorescent antibody test for American cutaneous leishmaniasis. American Journal of Tropical Medicine and Hygiene 32: 1260-1267, 1983.

119. Passwell J, Shor R, Heren G, Messer G, El-On J. Comparison of the effect of various stimuli on the leishmanicidal capacity of human monocytes in vitro. Clinical and Experimental Immunology 56: 553-558, 1984.
120. Pearson RD, Harcus JL, Symes PH, Romito R, Donowitz GR. Failure of the phagocytic oxidative response to protect human monocyte-derived macrophages from infection by Leishmania donovani. Joumal of Immunology 129: 1282-1286, 1982.

121. Pearson RD, Romito R, Symes PH, Harcus JL. Interaction of Leishmania donovani promastigotes with human monocyte-derived macrophages: parasite entry, intracellular survival, and multiplication. Infection and Immunity 32: 1249-1253, 1981.

122. Pearson RD, Wheeler DA, Harrison LH, Kay HD. The immunobiology of leishmaniasis. Reviews of Infectious Diseases 5: 907-927, 1983.

123. Pellegrino J, Pereira LH, Furtado TA. Mucocutaneous leishmaniasis intradermal test with a promastigote suspension and a crude extract from Leishmania braziliensis. Revista do Instituto de Medicina Tropical de São Paulo 19: 393-396, 1977.

124. Pereira LIA. Leishmaniose tegumentar. Estudo terapêutico baseado nos aspectos clínicos e imunopatológicos. Revista de Patologia Tropical 8: 181-241, 1979.

125. Pessoa SB, Pestana BR. A intradermorreação de Montenegro nas campanhas sanitárias contra leishmaniose. São Paulo Médico 15: 133-151, 1940.

126. Petersen EA, Neva FA, Barral A, Correa-Coronas R, Bogaert-Diaz H, Martinez D, Ward TE. Monocyte suppression of antigen-specific lymphocyte responses in diffuse cutaneous leishmaniasis patients from the Dominican Republic. Journal of Immunology 132: 1603-1606, 1984.

127. Petersen EA, Neva FA, Oster CN, Diaz HB. Specific inhibition of lymphocyte-proliferation responses by adherent suppressor cells in diffuse cutaneous leishmaniasis. New England Journal of Medicine 306: 387-392. 1982.

128. Poulter LW. Mechanisms of immunity to leishmaniasis. I. Evidence for a changing basis of protection in self-limiting disease. Clinical and Experimental Immunology 39: 14-26, 1980.

129. Preston PM, Dumonde DC. Experimental cutaneous leishmaniasis. V. Protective immunity in subclinical and self-healing infection in the mouse. Clinical and Experimental Immunology 23: 126-138, 1976.

130. Rabinovitch M, Dedet JP, Ryler A, Robineaux R, Topper G, Brunet E. Destruction of Leishmania mexicana amazonensis amastigotes within macrophages in culture by phenazine methosulfate and other electron carriers. Journal of Experimental Medicine 155: 415-431, 1982.

131. Reed SG, Badaró R, Masur H, Carvalho EM, Lorenço R, Lisboa A, Teixeira R, Johnson Jr WD, Jones TC. Selection of skin test antigen for American leishmaniasis. American Journal of Tropical Medicine and Hygiene 35: 79-85, 1976.

132. Reis MG, Roters SB, Barral-Netto M. Influence of immune serum on the internalization of Leishmania mexicana amazonensis in murine macrophages. (Enviado para publicação).

133. Rezai HR, Gettner S, Behforouz N. Antileishmanial activity of immune guinea-pig serum. Joumal of Medical Microbiology 5: 371-375, 1972. 
134. Ridley DS. A histological classification of cutaneous leishmaniasis and its geographical expression. Transactions of the Royal Society of Tropical Medicine and Hygiene 74: 515-521, 1980.

135. Roffi J, Dedet JP, Desjeux P, Garre MT. Detection of circulating antibodies in cutaneous leishmaniasis by enzyme linked immunosorbent assay. American Journal of Tropical Medicine and Hygiene 29: 183-189, 1981.

136. Rotberg A. Contribuição para o estudo da alergia na leishmaniose tegumentar americana. Tese de Doutorado, São Paulo, 1952.

137. Sacks DL, Scott PA, Asofsky R, Sher FA. Cutaneous leishmaniasis in anti-IgM-treated mice: enhanced resistance due to functional depletion of a B-celldependent $\mathrm{T}$-cell involved in the suppressor pathway. Journal of Immunology 132: 2072-2077, 1984.

138. Salles-Gomes L. A intradermorreação de Montenegro da leishmaniose e outras pesquisas afins. Brasil Médico 53: 1079-1087, 1939.

139. Scott $\mathbf{P}$. Impaired macrophage leishmanicidal activity at cutaneous temperature. Parasite Immunology 7: 277-288, 1985.

140. Scott P, Barral A, Martins E, Sher A, Marsden PD, Carvalho EM. Immunological resp snses in cutaneous and mucocutaneous leishmaniasis. Analysis of suppressor cell function in vitro. (Enviado para publicação).

141. Scott PA, Farrell JP. Experimental cutaneous leishmaniasis. I. Non-specific immunodepression in $\mathrm{Balb} / \mathrm{c}$ mice infected with Leishmania tropica. Journal of Immunology 127: 2395-2400, 1981.

142. Scott P, Sacks D, Sher A. Resistance to macrophagemediated killing as a factor influencing the pathogenesis of chronic cutaneous leishmaniasis. Journal of Immunology 131: 966-971, 1983.

143. Shaw JJ, Lainson R. Leishmaniasis in Brazil. XIX. Leishmanial and trypasonomal $\operatorname{Ig} A$ antibody in patients with leishmaniasis and Chagas' disease. Transactions of the Royal Society of Tropical Medicine and Hygiene 75: 254-257, 19

144. Sugarman B. Attachment of bacteria to mammalian cell surfaces. Infection 8: 132-141, 1980.

145. Titus RG, Ceredig R, Cerottini JC, Louis JA. Therapeutic effect of anti-L3T4 monoclonal antibody GK 1.5 on cutaneous leishmaniasis in geneticallysusceptible Balb/c mice. Journal of Immunology 135: 2108-2114, 1985.

146. Titus RG, Kelso A, Louis JA. Intracellular destruction of Leishmania tropica by macrophages activated with macrophage activating factor/interferon. Clinical and Experimental Immunology 55: 157-165, 1984.

147. Titus RG, Lima GC, Engers HD, Louis JA. Exacerbation of murine cutaneous leishmaniasis by adoptive transfer of parasite-specific helper T-cell populations capable of mediating Leishmania major - specific delayed - type hypersensitivity. Journal of Immunology 133: 1594-1600, 1984.

148. Turk JL, Bryceson ADM. Immunological phenomena in leprosy and related diseases. Advances of Immunology 13: 209-266, 1971.

149. Voller A, Bartlett A, Bidwell DE. Enzyme-immunoassays for parasitic diseases. Transactions of the Royal Society of Tropical Medicine and Hygiene 70: 98-106, 1976.

150. Voorhis WCV, Kaplan G, Sarno EN, Horwitz WA, Steinman RM, Levis WR, Nogueira N, Hair LS, Gattas CR, Arrick BA, Cohn ZA. The cutaneous infiltrates of leprosy. Cellular characteristics and the predominant T-cell phenotypes. New England Journal of Medicine 307: 1593-1597, 1982.

151. Walton BC, Brooks WH, Arjona I. Serodiagnosis of American leishmaniasis by the indirect immunofluorescent antibody test. American Journal of Tropical Medicine and Hygiene 21: 296-299, 1972.

152. Walton BC, Valverde L. Racial differences in espundia. Annals of Tropical Medicine and Parasitology 73: 23-29, 1979.

153. Walton BC, Valverde L, Eguia y Eguia O. Onset of espundia many years after occult infection with Leishmania braziliensis. American Journal of Tropical Medicine and Hygiene 22: 696-698, 1983.

154. Weintraub J, Gottlieb M. Leishmania tropica: Association of a B-cell mitogen with hypergammaglobulinemia in mice. Experimental Parasitology 53: 87-96, 1982 .

155. Weintraub J, Weinbaum FI. The effect of BCG on experimental cutaneous leishmaniasis in mice. Journal of Immunology, 118: 2288-2290, 1977.

156. Wyler DJ. In vitro parasite-monocyte interactions in human leishmaniasis. Evidence for an active role of the parasite attachment. journal of Clinical Investigation 70: 82-88, 1982.

157. Zehavi V, El-On J, Pearlman E, Abrahams JC, Greenblatt CL. Binding of Leishmania promastigotes to macrophages. Zeitschrift für Parasitenkunden 69: 405-414, 1983.

158. Zenian A, Rowles P, Gingell D. Scanning electronmicroscopic study of the uptake of Leishmania parasite by macrophages. Journal of Cell Sciences 39: 187-199, 1979. 